Article

\title{
Lear, Luke 17, and Looking for the Kingdom Within ${ }^{\dagger}$
}

\section{Emily E. Stelzer}

Department of English, Houston Baptist University, Houston, TX 77074, USA; estelzer@hbu.edu

+ I am deeply grateful to David Urban, the anonymous readers, and my colleagues David J. Davis and Lou Markos for valuable critique and gracious comments given on earlier drafts of this essay.

Received: 15 June 2019; Accepted: 26 July 2019; Published: 29 July 2019

\begin{abstract}
The ending to Shakespeare's Tragedy of King Lear has generated much debate. Performance history and critical interpretations of the conclusion of the Folio version of Lear have been pronouncedly divided into readings intimating the tragic hero's redemption and readings averring his ultimately bleak condition, whether of delusion or despair. Recent attempts to describe Shakespeare's use of scripture in this play have offered more nuance, acknowledging the play's blending of pagan and Christian elements. While King Lear has extensively been compared to the book of Job and to apocalyptic passages in Revelation and Daniel, allusions to the gospel narratives and to Luke in particular raise the thorny question of Cordelia's role as a Christ-figure. This essay argues that the ambiguous and suggestive nature of Lear's final words ("Look there, look there!") is both preserved and illuminated when read as an allusion to Jesus' words in Luke 17:21. This previously unexplored allusion not only offers guidance for responding to Lear's exhortation to "Look there" but also resonates within Shakespeare's play through shared themes of apocalypse, kingdom, sight/insight, and the importance of the heart.
\end{abstract}

Keywords: Shakespeare; King Lear; Cordelia; gospel of Luke; kingdom of God; look there; icon; image

"What gestures shall we appropriate to this? What has the voice or the eye to do with such things?" - Charles Lamb, On the Tragedies of Shakspere Considered with Reference to Their Fitness for Stage Representation, 1811

"We wish that we could pass this play over, and say nothing about it. All that we can say must fall far short of the subject; or even of what we ourselves conceive of it."-William Hazlitt, Characters of Shakespear's Plays, 1817

Among the famous last words of Shakespeare's tragic heroes, King Lear's "Look there, look there!" is perhaps the most controversial. ${ }^{1}$ Part of the controversy is due to textual discrepancies between the 1608 Quarto (True Chronicle Historie of the Life and Death of King Lear) and the 1623 First Folio (The Tragedie of King Lear). Variations in the final scene in particular, and even more particularly in the king's last words, have led one scholar to assert that Lear "presents the most fascinating, important, and contentious textual issues of the entire Shakespeare canon" (Ioppolo 2016, p. 1380). In the Historie (Q1), after requesting another to "undo this button," Lear cries out, "O, O, O, O," and, after Edgar says that the king faints and attempts to recall him, Lear's last words are "Break, heart, I prithee break" (Historie 5.3.306-8). In the Tragedie (F), this line is given to Kent after the king speaks these final, troublesome words:

1 The lines contend only with Hamlet's “The rest is silence." Hamlet's last words may be read in light of his earlier statement that "the readiness is all," which in turn bears fruitful contrast with Edgar's "the ripeness is all." See (Frye 1963, pp. 137-39). 
Lear. And my poor fool is hanged. No, no, no life?

Why should a dog, a horse, a rat have life,

And thou no breath at all? Thou'lt come no more,

Never, never, never, never, never!

Pray you, undo this button. Thank you, sir.

Do you see this? Look on her! Look, her lips,

Look there. Look there! (Tragedie 5.3.281-87) ${ }^{2}$

There are scholarly arguments for Q1 being based on Shakespeare's foul papers, for many variations in Q1 being attributable to the inexperience of printer Nicholas Okes and his compositors in typesetting drama, and for some eliminations in the Folio resulting from cuts made to the play in performance. ${ }^{3}$ Nevertheless, since Q1 has approximately 285 lines not found in F, and F has over 100 lines not found in Q1, "cutting the text to shorten the play for performance cannot have been the sole or main purpose for revising the text" (Halio 1994, p. 24). Textual issues provide matter for debate even in the question of whether it is best to think of Lear as essentially a single play (albeit one undergoing transformation in print and performance) or as two distinct versions. ${ }^{4}$ The extent to which Shakespeare had a hand in the changes between Q1 and F is also uncertain. Despite Q1's title page, there is some question about whether or not the earliest printed version of the play accurately reflects the version "as it was played before the Kings Maiestie at Whitehall"; the Folio title page declares the volume "Published according to the True Originall Copies," and John Heminge and Henry Condell's letter to the readers promises Shakespeare's words "as he conceived them." Scholarly consensus favors the carefully prepared Folio as the more authoritative version, although it does not indisputably represent Shakespeare's own final word on the play.

The significance of these questions is heightened by an ongoing dispute about the ultimate tone of the play, and whether or not Lear's final words in the Folio indicate a potentially redemptive moment. In both Q1 and F, the word redeem, after all, occurs twice at important moments in the play, both in connection with Cordelia. In Act 4, Cordelia's Gentleman says to Lear, "Thou hast one daughter / Who redeems nature from the general curse / Which twain have brought her to" (4.6.201-3). The two bringing the curse in the immediate context are Goneril and Regan; through allusion they are also Adam and Eve, responsible for the original sin whose curse is inherited by and taints all humanity. The analogy then puts Cordelia in the role of Jesus Christ, the second Adam, come to redeem humanity from that curse. ${ }^{5}$ From the opening scene, Lear expresses his hope that Cordelia will play a central role in his old age and in the transference of his kingdom. In Act 4, as Lear recognizes Cordelia's true worth,

2 Quotations of the 1608 Quarto text of The History of King Lear are taken from Jay L. Halio's edition for The New Cambridge Shakespeare (Shakespeare 1994). The Folio text above is taken from The Norton Shakespeare, 3rd ed. (2016). Elsewhere, if not otherwise noted, quotations from Lear correspond in act, scene, and line number with the text of The Arden Shakespeare (Shakespeare 1997a, Third Series, edited by Reginald A. Foakes) which favors the Folio text but gives clear, comprehensive indications of variants among Q1, Q2, and F (corrected and uncorrected). Quotations from other works by Shakespeare follow The Norton Shakespeare, 3rd ed. (2016).

3 See (Vickers 2016; Halio 1994, p. 4; Carson n.d.; and Ioppolo 2016).

4 See, for example, (Vickers 2016); (Taylor and Warren 1983); and T. H. Howard-Hill's essay, "The Two Text Controversy," in (Ogden and Scouten 1997, pp. 31-44).

5 Most annotated editions of Lear identify the "twain" as both Goneril and Regan and, more remotely, Adam and Eve (e.g., Shakespeare 1997a, pp. 342-43). The contrast of Adam and Christ is traditional. Romans 5:14-19 and 1 Corinthians 15:22, 45-49 connect Adam, the first man and the one whose first disobedience of God's law brought sin into the world, with Jesus, the second Adam, who lives sinlessly and whose death and resurrection redeems humankind. The pages for chapter 15 of 1 Corinthians in the 1595 Geneva-Tomson are among those that feature more commentary than sacred scripture, marking a significant and well-known portion of scripture on the essential Christian doctrine of the resurrection. The Book of Common Prayer's Order for the Burial of the Dead includes a "lesson" explicating the chapter, including assurances of the resurrection of the dead at the second coming of Christ and the contrast of Adam with Christ as the Second Adam. As the lesson was in the 1549, 1552, 1559 and 1604 versions of the Book of Common Prayer, anyone attending an Anglican burial service in Shakespeare's day would hear it. The reference to apocalyptic trumpets is there, as are references to the kingdom of God. Indeed, one might benefit from reading the whole of the Anglican Order for the Burial of the Dead alongside King Lear. 
the significance of her life or death intensifies for him. She is his salvation; she or what she represents may serve to save his whole kingdom. Yet at the second occurrence of the word redeem (again in both Q1 and F) Lear is holding Cordelia's corpse in his arms. In a moment when he allows himself to entertain thoughts of her revival, he says (in delusion, or sarcasm, or hope) "This feather stirs, she lives: if it be so, / It is a chance which does redeem all sorrows / That ever I have felt" (5.3.263-65). Both Q1 and F uphold the living Cordelia as the sine qua non of Lear's redemption at a moment when she is already dead, and moments before Lear's own passing. The Folio's "Look there!" may signify the delusional belief that Cordelia yet lives-one final cruel trick of the universe, or considered more cynically, its last best gift, the coup de grâce. Contradistinctively, these words might indicate Lear's true moral or spiritual progress, pointing to an authentic if limited redemption for the old king.

Understandably, there is scholarly resistance to readings of the play that support a non-ironic introduction of hope in Lear's final moments, especially given the glib moralizing of two alternative Lear stories that bookend Shakespeare's Jacobean play, and are distinctly not Shakespearean. The first is one of Shakespeare's main sources, the anonymous True Chronicle History of King Leir (1605), which is set in Christendom and is filled with expressions of piety and moral sentiment made easy by a happy ending. The second bookend is Nahum Tate's version, which bluntly alters Shakespeare's tragedy with its own happy ending and pious pronouncements, and effectively replaced Shakespeare's version on stage from 1681 until $1845 .^{6}$ Shakespeare's drastic divergence from the Leir story to his tragic narrative, and subsequently Tate's warping of Shakespeare's play into an audience-pleasing happy

6 In the anonymous Leir play, Gonerill and Ragan live to escape with their husbands, the Kings of Cornwall and Cambria (respectively), put to flight by Mumford and the troops of the King of Gallia, Cordella's spouse. King Leir survives to give a final speech praising his faithful nobleman Perillus (Kent's analog) and to provide a final speech on true love, modest words, and reward for those loyal through hardship.

In Nahum Tate's version, Edgar and Albany step in at the last minute to prevent the deaths of Lear and Cordelia, Lear is restored to his throne, and Cordelia and Edgar are married. Kent gains the long-awaited reward of Lear's recognition and approbation: "Why here's old Kent and I, as tough a Pair / As e'er bore Tyrant's stroke." The gods fare better in this play, too. Edgar assures Cordelia of his role as divine agent of justice:

"My dear Cordelia! Lucky was the Minute

Of our Approach; the Gods have weigh'd our Suff'rings;

W'are past the Fire, and now must shine to Ages." (Bonheim 1960, p. 4)

Cordelia describes Albany as a deus ex machina: "Speak, for methought I heard / The charming voice of a descending God"; and when Albany returns a kingdom to Lear, Cordelia concludes, "Then they are Gods, and Virtue is their Care." Lear is heroically forgiving and sentimental enough to feel some pangs at the news of Goneril's and Regan's deaths, and his bestowing of the kingdom and his daughter's hand on Edgar is accounted overcompensation for present virtue and past sufferings:

Edg. The Gods and you too largely recompence

What I have done; the Gift strikes Merit dumb.

Cord. Nor do I blush to own myself o'erpaid

For all my Suff'rings past.

Peace and Plenty are immediately restored, and Edgar's final thought pins the happy ending on Cordelia's goodness: "Thy bright Example shall convince the World / (Whatever Storms of Fortune are decreed) / That Truth and Virtue shall at last succeed."

For most readers and critics today, this version smacks of sentimentality, cheap poetic justice, and tired piety, although modern audiences have well received the Tate version when revisited as a curiosity (Ristad 1985, p. 8). The happy ending dissatisfied Joseph Addison and August Schlegel; it was excoriated by Charles Lamb, William Hazlitt, and Anna Jameson-yet this was the version dominating the stage until 1838 (Wells 2000, p. 63). Samuel Johnson sided with the general public in his preference for a happy ending where virtue is rewarded, and he defended this impulse with a personal anecdote: "And, if my sensations could add any thing to the general suffrage, I might relate, that I was many years ago so shocked by Cordelia's death, that I know not whether I ever endured to read again the last scenes of the play till I undertook to revise them as an editor" (Bonheim 1960, p. 12). It was the Tate version of Lear that David Garrick played to much acclaim; William Charles Macready is lauded today as the actor who made the successful return to Shakespeare's tragic ending in 1834 (after Edmund Kean's unpopular attempt to do so in 1823), although the full restoration of Shakespeare's text on stage was not complete until Samuel Phelps's performance in 1845 (Wells 2000, p. 69). In the United States, Tate's version remained standard until Edwin Booth's performance in 1875. Now the whirligig of taste has turned to find the comic ending laughably unconvincing. 
ending, might make one wary of any apparent attempt to cram Shakespeare's majestic tragedy into the (apparently) smaller world of tragicomedy.

It would be unfair to lump all scholarship and performances that seek to illumine the potential for redemption in Shakespeare's play with the moralizing and comic impulses that shaped Leir and the Tate version. Even readings that argue for parallels between Lear and the medieval mystery or morality plays are careful to distinguish their approaches from such impulses. ${ }^{7}$ Sensitive resistance to the darkest of interpretations of Lear still remains and even may have its origins in Shakespeare's lifetime. In fact, some scholars have recently suggested that the changes between First Quarto and First Folio indicate revisions in response to audience demands, designed to affect the play's general outlook and ultimate effect. For example, Grace Ioppolo argues the difference between the Quarto and Folio texts "seems to suggest a carefully planned attempt by Shakespeare to alter the play's theatrical impact" (Ioppolo 2016, p. 1381). Christie Carson presents the matter more boldly: "[T]here is strong evidence the changes between the Quarto and the Folio were made as a result of the audience response to the play during Shakespeare's lifetime. The ending, in particular, is altered to change it from a scene of absolute despair to a scene of possible redemption and rebirth. Hope is reintroduced into the Folio ending of the play, something that makes this tragedy more poignant but also more bearable in its Folio form" (Carson n.d.). Carson acknowledges that this possibility for a "more bearable" tragedy may or may not be actualized on stage: "The reintroduction of hope in Lear's last line can be performed either as redemption and absolution or delusion. As is true of so much of Shakespeare's work, these lines are ambiguous."

In any interpretation of Lear, much depends on what is done with Lear's last words; much also depends on what is made of the biblical allusions throughout the play, including but not limited to the passages suggesting Cordelia's role as a Christ-figure. The present essay addresses both of these critical tasks, reviewing the performative and critical history involving Lear's final moments, and positioning these moments within the larger context of the play's environment and its characters' attitudes toward the gods and matters pertaining to the philosophy of religion. Ultimately, it argues for a previously unexplored allusion to Luke 17:21 in Lear's last line, an allusion which supports the play's ambiguity —and both its pagan setting and its Christian context-while emphatically redirecting the reader to a central concern of the play: the spiritual realm of the heart.

\section{1. “Look There!": Examples from Performance History}

Theatrical performances and cinematic productions of Lear customarily base their script off of the Folio text or a conflated text that is itself based off of the Folio; as a result, Lears tend to die saying, "Look there!" Yet even if after considering all textual variations one settles on the Folio ending, an astounding range of performative and interpretive options remain. ${ }^{8}$ In his extensive compilation of major interpretations of the play by actors, directors, and critics, Marvin Rosenberg reflects, "Much critical interpretation of Lear pivots on [Lear's last] seven lines [in F], and indeed almost entirely on the last two" - lines that "have been seized upon by 'redemptionists' as casting a warm and hopeful glow over the dark and deadly scene" (Rosenberg 1972, pp. 318-19). Where Lear looks, how he looks, and what he sees or thinks he sees affect the final and overall impression of the play.

Consider first the question of where Lear so urgently requires his audience's attention. While some performances and productions have featured the aged king speaking his last words while looking distantly up or out, the consensus is supported by context-Lear is looking down at the body of Cordelia and seeking to draw the attention of all to her. It is possible for Lear's attention to shift between "Do you see this? Look on her! Look, her lips," and his next and final line, although the

7 See, for example, (Guilfoyle 1989, pp. 57, 66; Campbell 1948, pp. 93-109).

8 This examination of a few key examples is necessarily limited. For a guide to further reading that examines problems faced by the theatre historian and provides a list of notable performances and scholarly approaches to the performance history of Lear, see (Smith 2006, pp. 35-38). 
pattern in Lear's final utterances is one of temporary distraction and then emphatic return to Cordelia. Indeed, Cordelia is Lear's utmost and ultimate concern; others may be presented to him only to become foils to offset the true jewel of his eyes. Faithful Kent seeks recognition as Caius; Lear brushes him off: "I'll see that straight" (5.3.285). The deaths of Goneril and Regan are revealed; Lear numbly assents: "Ay, so I think" (5.3.290). Albany observes, "He knows not what he says and vain is it / That we present us to him"; the ensuing announcement of Edmund's death Albany dismisses as "but a trifle here," and Albany's own underdeveloped plans for restoring justice are cut short as his "O, see, see!" gives

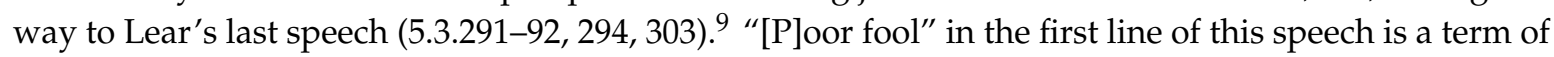
endearment referring to Cordelia, although some have inferred that here the aged king distractedly reveals the manner of his Fool's death. ${ }^{10}$ Even if Lear's Fool is recalled here, there is little cause to doubt that the king's attention is ultimately, exclusively fixed upon Cordelia, that his attention does not waver between "Look on her: look, her lips" at the end of his penultimate line and "Look there, look there!" in his last one. Even the undoing of a button is only superficially a distraction. ${ }^{11}$ The interruption of the mundane is here a reminder of Lear's bodily frailty at a moment of psychological intensity, as he once more struggles to keep down "this mother" that "swells up toward [his] heart," "Hysterica passio" (2.2.246-47); Wittingly or not, Lear prepares his heart to expand, and thence to break. With Cordelia's corpse in his arms, what could make Lear desire to be stretched out longer upon the rack of life?

Yet within this dismal scene, Lear vacillates between expressions of certainty at his daughter's death and expressions of hope that she is yet alive. When he enters the scene carrying Cordelia's corpse, his howls are both cries and commands, onomatopoetic and imperative. ${ }^{12}$ He rebukes the stunned observers ("O, you are men of stones!") and then announces, "She's gone forever. / I know when one is dead and when one lives; / She's dead as earth" (5.3.257-59). Nevertheless, soon afterward,

9 Of Albany's final attempt to restore justice, Greg Maillet remarks, "The blindness of this comment is so obvious, the sentiment so clearly untrue and particularly unfair to Cordelia and Lear, the imagery so contrary to the blindness/sight paradox developed so clearly to this point in the play, that there can be no question that Shakespeare is again using Albany to express an at best naïve and at worst obtuse sentiment about suffering" (Maillet 2016, p. 116).

10 Yet even here commentators resist expressions of certainty, for the affectionate tone "does not force a choice between Fool and Cordelia" (Rosenberg 1972, p. 318), and the name recalls not only the disappearance of the Fool after Act 3 scene 6 , but also the tenderness and compassion Lear learns to express toward his companion on the heath (3.2.68-73; 3.4.26). Marvin Rosenberg records that the actor John Gielgud "speculated that Cordelia and the Fool were probably much alike because played by the same actor" (Rosenberg 1972, p. 318), and it has become a conventional theatrical option to have the same actor play both roles.

The moniker may serve as a reminder that, even as the purported fools of this play have proven themselves quite wise in retrospect, such wisdom is no security against earthly vicissitudes. The purported fools include the Fool, Cordelia, Kent, Edgar, Albany, and Lear. The Fool offers Kent his coxcomb for faithfully attending the disgraced Lear in 1.4.93-100 and directly calls him Fool in 2.2.276. Kent says he is treated as a fool by Cornwall in 2.2.80. Outside the hovel, in the company of Lear, Kent, and Edgar in the guise of Poor Tom, the Fool says, "This cold night will turn us all to fools and madmen" (3.4.77). Edmund scorns Edgar for his "foolish honesty" in 1.2.179, and upon meeting his blinded father, Edgar remarks, "Bad is the trade that must play fool to sorrow" (4.1.40). Directly and indirectly, Goneril calls Albany a fool five times in Act 4 , scene $2(28,38,55,59,62)$. The Fool calls Lear foolish several times, beginning at 1.4.104, and Lear assumes this title in repentance and in preparation for the restoration scene with Cordelia (4.6.187, 4.7.60, 84). For wisdom in foolishness, compare Paul's assessment of the Christian faith in 1 Corinthians 1.

For the scholarly consensus supporting the primary sense of "my poor fool" as a reference to Cordelia, see, for example, editorial notes for this line in The Norton Shakespeare (Shakespeare 2016, p. 1460), David Bevington's edition of The Complete Works of Shakespeare (Shakespeare 2014, p. 1254), The Riverside Edition (Shakespeare 1997b, ed. Baker et al., p. 1343), Russell Fraser's edition of King Lear for the Signet Classic Shakespeare (Shakespeare 1998, p. 144), and R. A. Foakes's edition of King Lear for the Arden Shakespeare (Shakespeare 1997a, ed. Foakes, p. 390).

11 The button is generally understood to be Lear's, although in performance the button is sometimes Cordelia's; in Shakespeare's time Cordelia would have had laces instead (Craik 1981, p. 173 n. 2). Cf. Paulina in The Winter's Tale: "Oh, cut my lace, lest my heart, cracking it, / Break too" (Winter's Tale 3.2.170-71). Lear has already set a precedent in unbuttoning himself to symbolic effect in the storm on the heath (3.4.107). Granville-Barker sees in Lear's "call for a looking-glass, his catching at the feather to put on Cordelia's lips, the undoing of a button" a "tragic beauty" and "the necessary balance to the magniloquence of the play's beginning and to the tragic splendor of the storm" (Granville-Barker 1940, p. 160). See also (Rosenberg 1972, p. 319); (Bradley 1991, p. 270).

12 Benedict Nightingale lists several options for these howls from performance history: "Sinden, Church, Olivier on television, and Stephens transformed the repetitions of 'howl' into a long animal wail of grief. With Michael Redgrave ... [1953], the words were a kind of exhausted baying. Scofield invested them with a terrible rage as well as with pain. With Cox and Gambon, they were more obviously an order to the stunned spectators" (Ogden and Scouten 1997, p. 242). 
Lear seeks some visible sign of Cordelia's breath in the fogging of a glass or the "stain[ing] of a stone" (5.3.259-60). ${ }^{13}$ At the stirring of a feather, he briefly entertains hope she yet lives; it is the "chance that does redeem all sorrows" (264). Kent's cry of pity at his master's struggle to confront unbearable sorrow only causes Lear to turn on his attendants: "A plague on you murderers, traitors all; / I might have saved her; now she's gone for ever" (5.3.267-68). This second outburst and confirmation of Cordelia's death immediately reverts to uncertain hope as Lear again fixes his attention upon his daughter: "Cordelia, Cordelia, stay a little. Ha? / What is't thou sayst?" (269-70). The breath he wishes would "stain the stone" is especially precious to him as evidence of her communicative powers, for he has finally learned to listen for, value, and respond to Cordelia's voice, "ever soft, / Gentle, and low, an excellent thing in woman" (5.3.270-71). From the opening scene, Kent had advised Lear that Cordelia's refusal to participate in the contest of love speeches was a sign of her virtue, not her lack of love: "Nor are those empty-hearted, whose low sounds / Reverb no hollowness" (1.1.154-55). From Lear's tempestuous dismissals of Kent, Cordelia, and the wisdom within their unadorned speeches, the king must spend much of the rest of the play learning the hard way to esteem Cordelia properly, to recognize, value, and accept a love that quietly and stubbornly confronts folly, flattery, and falsehood. The awful tragic irony is that just as Lear learns this, Cordelia is silenced in death. He staggers between agony and denial. With Lear's final command-“Look on her: look, her lips, / Look there, look there!"- one may reasonably assume Lear dies looking for life on the lips of his beloved child-perhaps even for a word of truth and love, soft, gentle, and low (5.3.309-10). Whether his final exclamation should be interpreted as evidence that he ultimately sees or thinks he sees a sign of such life are additional matters for dispute.

The critical and performative controversy consequently includes the question of how Lear looks in these last moments. On stage, in film, and in critical analyses, a panoply of Lears have died in delusion or in wizened disillusion, invigorated or enfeebled, with keenness or with dullness of vision, with acceptance or with defiance, with utter grief, dementia, illumination, horror, ecstasy, stark despair, or apparent hope, whether within this world, or as if looking beyond a mortal vale of tears to solace or peace or redemption or beatitude in an afterlife. Thus, Rosenberg reflects: "What does Lear see? Let the argument over its meaning wait: for the perception itself, it may be: an ecstatic illusion that Cordelia is alive, that at last she speaks the words he wants to hear; a vision of some supernatural aura about her, presumably beatific; even an apparent glimpse of her spirit, rising toward heaven; or a horror of the ultimate silence that has stilled her" (Rosenberg 1972, p. 319). Performance history supports these options. "Possible modes of Lear's dying" include, as Rosenberg summarizes, that of "Gielgud [1940], dying grandly in joy at his perception of apotheosis in Cordelia; Forrest, frankly hallucinating her reviving, staring vacantly into space; Carnovsky, shocked to death at the horror of Cordelia's stillness" (Rosenberg 1972, pp. 319-20). ${ }^{14}$ Major theatrical performances since Rosenberg's

13 As the Norton Shakespeare glosses it, Lear's hope that Cordelia's breath might "stain the stone" refers to "Mica, or stone polished to a mirror finish" (Shakespeare 2016, p. 1459). The OED records (sv. stain, v.) the possibility that stain and stone have shared linguistic roots: "Some of the English senses, both of stain and distain, are difficult to account for; it is possible that in Anglo-Norman the prefix des- in desteindre may sometimes have been taken in the sense 'diversely, differently'; it is also possible that the verb of French origin may have coalesced with an adoption of Old Norse steina to paint, $<$ stein-n paint, probably identical with stein stone." A pun here would then be etymological as well as aural. "Stain the stone" could be understood in light of a couple of archaic senses of the verb: " $+1 . b$. Of the sun, etc.: To deprive (feebler luminaries) of their lustre. Also figurative of a person or thing: To throw into the shade by superior beauty or excellence; to eclipse. Obsolete. (Very common in the 16th cent.),"or "+1.c. To obscure the lustre of. Literal and figurative. Obsolete." Shakespeare uses these related senses of the word when writing of the Fair Youth in Sonnet 33: "Yet him for this, my love no whit disdaineth: / Suns of the world may stain, when heaven's sun staineth" $(13,14)$; (Shakespeare 2001, p. 177). In Lear, a sign of Cordelia's life might not only fog the mirrored glass; it would obscure the lustre of any shiny object; it would eclipse any other luminary on stage. Put another way, Cordelia's death permits Lear to retain the role of tragic hero-for who would pity the man if his greatest hope were realized in his final moments of life?

14 The performances mentioned are those of John Gielgud (1940, dir. Lewis Casson, Harley Granville-Barker, The Old Vic); Edwin Forrest (1836); Morris Carnovsky (1963, Stratford Shakespeare Festival, CT, dir. Allen Fletcher). 
wide-compassed work naturally expand the repertoire, from James Earl Jones to Glenda Jackson. ${ }^{15}$ Performance historians and critics have compiled other lists of possibilities for how to "Look there!" Here is Benedict Nightingale:

Richard Briers's inconsolable Lear simply pointed at Cordelia's lips to show that there was no life there at all. On the other hand, Gielgud [1955] died in joy at what he interpreted as evidence of her revival. Stephens, somewhat eccentrically, looked not at her lips but at a point offstage where, as he explained in an interview, he was seeing Cordelia in one of those point-of-death experiences the survivors of which have described as going through a long golden tube into paradise. Scofield died sitting up, staring vacantly into the vast empty universe that had left him such a ruin. (Ogden and Scouten 1997, p. 243) $)^{16}$

And here is yet another compilation from Greg Maillet:

Welles does not speak the Folio's final lines at all, dying after the "Never, never ... " line. Olivier clearly sees something, and seems to die at peace, head in Cordelia's bosom, but McKellen's Lear dies clearly deluded, head snapping back and hardly looking at his daughter. Holm's Lear effectively alternates appearing mad and saner than those around him, while his 'look there' to whomever unbuttons his tight shirt convincingly claims sight of Cordelia's breath, or at least her spirit. (Maillet 2016, p. 118) ${ }^{17}$

However, Lear's final moment is performed, Nightingale assumes "the precise state of Lear's mind at this point need not ... be of overwhelming significance. Whether he dies 'happily' or not, he is dead and so is Cordelia. A few moments after he has been filled with joy and hope of reconciliation, the cruelty of men, of the universe or of both, has been devastatingly demonstrated" (Ogden and Scouten 1997, p. 243). Lear may die in ecstatic joy or insistent hope, but seen as symptomatic of delusion, such joy and hope might rather serve to increase the devastation of the tragedy's final effect. Maillet proposes a quite different response: "Regardless of what one sees in the theater ... we should be open to the possibility that [Cordelia is alive], and open to the corresponding potential for joy rather than sorrow being our dominant concluding emotion" (Maillet 2016, p. 118).

Among 'redemptionist' interpretations of Lear, Gielgud's 1940 performance at the Old Vic may be considered a focal point in performance history. This particular Lear reflected the coaching of Harley Granville-Barker, whose grand influence is partly captured in Gielgud (1963) Stage Directions, where some of Granville-Barker's notes appear in appendix. ${ }^{18}$ Barker's note for Lear's "Look on her" was simply annotated "Joy," associating Lear's last emotion with the first pet name the audience hears

15 Performances mentioned are those of James Earl Jones (1973, New York Shakespeare Festival, dir. Edwin Sherin) and Glenda Jackson (2019, Broadway, dir. Sam Gold). Jones played Lear's final scene as "a walking dead man," his howls barely audible, his physical strength eroded, his attitude conveying helplessness and resignation, and his death accompanied by a "long shuddering exhale-a great sigh of relief at being done with the agony he had suffered" (Jorgens 1973, p. 425). Glenda Jackson imperiously appeared on a set most reviews have not failed to associate with Trump Tower, herself "towering even in Lear's infirmity" (Soloski 2019). Her commanding presence was said to have drawn on "supernatural reserves of stamina" as "the sharp shock of Cordelia's death ... [was] presented [onstage] with a brutality that amplifie[d] the pathos of the broken king," whose "abject diminishment seem[ed] all the more powerful given the steely authority that precede[d] it" (Rooney 2019).

16 Performances mentioned are those of Richard Briers (1990, dir. Kenneth Branagh, Renaissance Theatre); John Gielgud (1955, dir. George Devine); Robert Stephens (1993, dir. Adrian Noble); Paul Scofield (1971, dir. Peter Brook).

17 Performances mentioned are those of Orson Welles (1953, dir. Peter Brook); Laurence Olivier (1983, dir. Michael Elliott), Ian McKellen (2008, dir. Trevor Nunn); Ian Holm (1998, dir. Richard Eyre).

18 The program for the 1940 Lewis Casson production announced a performance "based on Harley Granville-Barker's 'Preface to King Lear,' and his personal advice besides," and, despite Barker leaving London before opening night, there is strong evidence of the intensity and thoroughness of Barker's coaching, and that "the production was essentially [Granville-Barker's]" (Leggatt 2004, p. 25). The production emphasized Lear's "constant variety" and took for granted, as Alexander Leggatt reflects, "a Lear capable of growth and change, of new insights and new experience," but whose "progress was not easy or glib" (Leggatt 2004, pp. 29-30). The crowning effect of this progress, which was "for many observers the most important effect of Gielgud's performance," was real and substantial moral, intellectual, and spiritual 
Lear give Cordelia-“Now, our joy” (1.1.80) (Leggatt 2004, p. 29; Gielgud 1963, p. 129). ${ }^{19}$ The thought of Cordelia alive- the chance that does redeem all sorrows-becomes the final joy of Gielgud's Lear.

Chief among the bleaker sort of Lears is Peter Brook's 1962 stage production with Paul Scofield in the title role, described by Jonathan Croall as "iconoclastic" and "the watershed moment in the play's more recent stage history" (Croall 2015, p. 2). Brook's version was hailed as representative of the modern world, bleak, absurd, and grotesque, considered culturally and historically significant, and influenced by Jan Kott's 1962 essay "King Lear, or Endgame."20 The production became a paradigm for the nihilist/absurdist/existentialist camp, as did the 1971 film version [again with Paul Scofield as Lear] which developed from it. Roger Ebert described the film as occupying "a barren kingdom frozen in the middle of a winter that chills souls even more than bodies," at the end of which, "[b]urdened by senility and a sense of overwhelming futility, [Lear] collapses gratefully into death" (Ebert 1972). This is "Brook's Lear, ... not Shakespeare's," Ebert emphasizes, and "interesting precisely because

growth (Leggatt 2004, p. 30). See also Leggatt's comments on "Player in Action," Hallam Fordham's manuscript in the Folger Library (Leggatt 2004, pp. 25-35).

From Granville-Barker's Preface to Lear, one may trace the redemptionist influence further back to A. C. Bradley. The Preface to Lear engages frequently with Bradley, and not uncritically. In particular, Granville-Barker finds Bradley's apparent desire for "a single performance to make a clear, complete and final effect on the spectator" to be "too sophisticated," too critically removed from the variety and unruliness of the theater (Granville-Barker 1940, pp. 136, 138). Gielgud's 1940 Lear reflects Barker's insistence that "variety and inconsistency gives great vitality" (Granville-Barker 1940, p. 93), for dramatic art should seek to imitate life's complexity, and "the immediate effect" of a great work of art "will be made a little differently upon each of us, and for each of us may differ from time to time" (Granville-Barker 1940, p. 138). Nevertheless, the dynamic Lear of Gielgud and Barker ends up where Bradley's does. Granville-Barker points to Bradley's "admirable note" upon Lear's final words, asserting that Bradley's suggestion that Lear dies of joy in the thought that Cordelia lives "a fine piece of perception" (Granville-Barker 1940, p. 185).

19 Granville-Barker also notes the association of Cordelia and Joy in his Prefaces (Granville-Barker 1940, p. 165). The Preface to Lear emphasizes balance between the opening and final scenes (Granville-Barker 1940, pp. 154-55, 160, 184). The king has learned to hear her soft and low message of love.

20 Brook's stage production was rehearsed as the Cuban missile crisis escalated fears of nuclear destruction, and "Brook associated the play with current anxieties about the hydrogen bomb, the Cold War and the concept of mutual assured destruction" (R. A. Foakes in Shakespeare 1997a, p. 32; see also Croall 2015, p. 44; Leggatt 2004, pp. 59-60). Charles Marowitz, Brook's assistant director, observed that during rehearsals "the frame of reference was always Beckettian" - although both Scofield and Brook later downplayed this influence, and Leanore Lieblein has defended Brook's Lear as "dynamic and independent in its relation to Kott" (Croall 2015, pp. 40-41; Leggatt 2004, p. 55; Lieblein 1987, p. 46; cf. Kott 1974). Ken Tynan's influential review captured the production's "revolutionary" decisions: Kent was a "ruffian," Gloucester was "shifty," and Lear, no longer the "majestic ancient," "deserves much of what he gets" (qtd. in Ogden and Scouten 1997, p. 188). His knights were vandals. The sympathetic servants at the blinding of Gloucester and the last-minute reform of Edmund were cut. Cordelia was more stubborn than saintly, and, as Carol Rutter has elucidated in detail, Goneril was emotionally retracted, "drain[ing] sympathy from the scene," refusing to offer "a reaction that would absorb the damage Lear was doing." Paralleling Lear's disowning of Cordelia and his cursing of Goneril, "Brook's direction bid for continuity" between the eldest and youngest daughter (Ogden and Scouten 1997, p. 190). The elder daughters were no longer fiends; Lear, not Goneril, had bemonstered himself (Ogden and Scouten 1997, pp. 188, 191). Edmund Gardner described Lear's final moments as “horribly moving. 'Howl, howl, howl!' freezes the blood, while his sorrow over the dead Cordelia packs ice into the bones" (qtd. in Leggatt 2004, p. 59). So different in his own approach, John Gielgud saw the production in Philadelphia and spoke graciously of it to Irene Worth, who played Goneril: "One cannot hope in such a mighty work to achieve more than two-thirds perfection—and that I think this production does" (Croall 2015, p. 46).

Film has additional resources for revealing or hiding that which may be seen-by introducing hallucinations of the living Cordelia, for example, or cutting out of the frame the very object upon which the dying Lear's attention is fixed. Carol Rutter analyzes these decisions in Peter Brook's 1971 film version. The final scene denies the viewer a glimpse of Cordelia's body from "Had I your tongues" forward, introduces hallucinations of Cordelia, puts the camera in the corpse's position, and ends with a closeup of Lear in which his "eyes, like his hand, travel upwards" enigmatically—perhaps because he sees Cordelia above him, perhaps because his head is tilting back in death, slipping out of the frame, leaving only a "gray expanse of sky" (Ogden and Scouten 1997, p. 211). The viewer neither sees signs of life in Cordelia's corpse nor is given the dismal satisfaction of seeing that there are none. This version, Rutter observes, "denies the audience the grim pleasure of spectating on Cordelia's body" and "refuses to indulge our cultural fascination with female victimization represented on film" (Ogden and Scouten 1997, p. 211).

The 2018 film adaptation for Amazon Studios (dir. Richard Eyre) offers a different take on limiting the audience's vision of Lear's final moments. There, apocalyptic, washed-out grays set the mood for a grim military environment. Sir Anthony Hopkins's Lear reveals Cordelia's death with a sharp, curt, and vigorous "She's gone," whence a thin cloak of emotional control is dropped to expose trembling rage and grief. Between Hopkins's Lear's final expressions of sorrow at Cordelia's death and the close-up on his countenance at the agonizing moment of his own passing, the camera angles change to show Lear's hand pointing to the still corpse of his daughter; the frame denies the viewer any revelatory glimpse of Lear's face during his final gesture and command-as if paying tribute to the lack of consensus on how Lear ought to look at this enigmatic moment. Any mystery or curiosity shifts from the dead Cordelia to the dying Lear. 
it contrasts so firmly with Shakespeare's universe; by deliberately omitting all faith and hope from Lear's kingdom, it paradoxically helps us to see how much is there."

For each performance or production, one might further consider how the spectator is invited to view Lear's death. Are we asked to imitate Lear in his grief, as he commands onlookers to howl with him at the entrance of Cordelia's corpse (5.3.255)? Are we invited to a position of dramatic irony, where we may take refuge in a superior vantage point and the superior knowledge it affords? Should we join Kent, who [in the Folio] prays for the broken heart, or Albany, who offers verbal assurances of distributive justice to come, or Edgar, who says he must obey "the weight of this sad time" and "speak what we feel, not what we ought to say," and who, as a young man, separates himself respectfully from the experience of the old (5.3.301-3, 311, 322-25)? Does the play encourage one perspective more than another? Rosenberg asserts, "The facts of the text are that Cordelia is physically dead, and that all about her-except possibly Lear-see nothing to alleviate a sense of absolute woe" (Rosenberg 1972, p. 319). But even if this statement adequately describes a shared perspective of the characters on stage, should it be the audience's and the reader's, too?

Fashions change, but the debate and the theater's indebtedness to past interpretations continues. Bradley's perspective has retained its influence, as has Brook's. ${ }^{21}$ Each position has a distinguished pedigree. Brook's approach is often presented as an intriguing historical artifact, yet audiences continue to find the bleaker Lears compelling; conversely, the Gielgud-Barker-Bradley approach, in which the dying king seems to envision the living Cordelia as the alpha and the omega of his joy, is not quite dead.

\section{The Christianizers and the Existentialists}

The play's ability to support widely varying performances is greatly due to its consideration of enduring religious and philosophic questions. A play with a pagan, pre-Christian setting but designed for a culturally Christian Jacobean audience, King Lear raises questions of divine justice, fate, predestination, redemption, despair, sin, suffering, inner spiritual worth, altruism, and sacrificial love. The varied performance history is matched by starkly opposed readings in the criticism; the play and readings of the play have been described as existentialist, absurdist, nihilist, Marxist, pagan, Christian, neo-Christian, and post-Christian —all terms unavailable to the eighth century B.C.E., the

21 Bradley's persistent influence is captured by Christopher Plummer, who had played Lear in Ontario's Stratford Festival under Sir Jonathan Miller's direction in 2002. In a 2015 interview, Plummer reflects,

The extraordinary thing about that scene-is it despair at the end? No, it's not. It's ecstasy. It's a sublime death that Lear is experiencing, and it really-it really is the happiest of all deaths... [H]e now knows what love is, really. Cordelia has to sacrifice herself in some way. She has to go. She has to die to make him see ... . But I think he's not just found Cordelia. I think he's found everything in life that he missed, and the beauty of it that he longed for. The tragedy of the play is that it's too late. ("King Lear with Christopher Plummer." 2015. Shakespeare Uncovered Season 2, episode 2. Public Broadcasting Service)

On the other side, English actor Tobias Menzies, who played Edgar at the Young Vic in 2009 under Rupert Goold's directorship (and later Cornwall in the 2018 Amazon Studios production), associates existentialism with the "Dover Cliff" scene in particular. After asserting "There is nothing elegiac or redemptive about the end of Lear," Menzies connects this to the Gloucester plot:

Edgar is trying to lead his father out of despair, but rather than using kindness he uses a rigorous existentialism. Edgar does not comfort his father; he does not say, 'Dad, don't worry, I'm here. I'm your son. Everything's going to be fine.' Instead he says, 'You want to die, and rightly so. Terrible things have happened to you.' The proposition is that the only real cure is to actually look at what it is to die, and so Edgar creates this existential experiment. (Carson 2013, pp. 73-74)

Interestingly, Menzies adds, “There's something in it that's quasi-religious, in a way. 'Thy life's a miracle' (4.5.65), says Edgar. To live is to endure, to suffer, and at the same time it's also a blessing" (Carson 2013, p. 74). In performance, the joyful interpretations of the end of Lear tend to retain something poignantly tragic, while the existentialist productions are often blended with something at least quasi-religious. 
presumed historical setting for the legendary king of Albion-and all but two terms unrecognizable within Shakespeare's own milieu. ${ }^{22}$

Scholarly debate on the extent to which the dying king demonstrates any ultimate insight, moral progress, or redemption has been especially active from the beginning of the twentieth century. In 1904, A. C. Bradley argued the play's "final and total result is one in which pity and terror, carried perhaps to the extreme limits of art, are so blended with a sense of law and beauty that we feel at last, not depression and much less despair, but a consciousness of greatness in pain, and of solemnity in the mystery we cannot fathom" (Bradley 1991, p. 257). Bradley's description of this effect upon the audience correlates with what he understood as an effect upon Lear himself: "The old King ... sees at last how power and place and all things in the world are vanity except love, [and] tastes in his last hours the extremes both of love's rapture and of its agony, but could never, if he lived on or lived again, care a jot for aught beside- there is no figure, surely, in the world of poetry at once so grand, so pathetic, and so beautiful as his" (Bradley 1991, p. 262). For Bradley, the dying king's final experience of love is connected with the expectation of redemption, with little room for ambiguity:

He is sure, at last, that she lives: and what had he said when he was still in doubt?

She lives! If it be so,

It is a chance which does redeem all sorrows

That ever I have felt!

To us, perhaps, the knowledge that he is deceived may bring a culmination of pain: but, if it brings only that, I believe we are false to Shakespeare, and it seems almost beyond question that any actor is false to the text who does not attempt to express, in Lear's last accents and gestures and look, an unbearable joy. (Bradley 1991)

A. C. Bradley's summative challenge-“'Should we not be at least as near the truth if we called this poem The Redemption of King Lear?"- fueled a persistent and heated debate regarding Lear's final perspective and the tragedy's final perspective on the human condition more generally (Bradley 1991, p. 262). Sharp division among critics contributed to what Helmut Bonheim in 1960 called the "King Lear Perplex," a series of interpretive cruxes that lead beyond scholarly debate to aporia or stalemate. Following a season favoring Jan Kott's approach as popularized by Brook's productions, and a reaction to the same, in 1975 John E. Van Domelen could indicate two interpretive camps, "the Christianizers and the existentialists": "those who see Lear as depending on a Christian framework of values for its meaning," reading the play as "a terrible theodicy," and "those who see Lear deriving its values solely from the choices of the characters," resulting in a "profoundly pessimistic view of the human condition" (Van Domelen 1975, p. 132). The identifiers shift, the arguments grow increasingly sophisticated and qualified, and the debaters have generally become more comfortable with uncertainty, yet the interpretive camps—-the "nihilistic and Christian," the "atheistical and Christianizing," the "neo-Christian [and] historicist"—remain (Shell 2010, pp. 186, 195; Hamlin 2013, p. 332). Categorizing

22 In Geoffrey of Monmouth's 12th-century account, after the deaths of King Leir and Cordelia, her nephews Margonus and Cunedagius engage in war ending in Cunedagius gaining the throne. Geoffrey then contextualizes these events: "At that time Isaiah was making his prophecies; and on the eleventh day after the Kalends of May Rome was founded by the twin brothers Remus and Romulus" (Geoffrey of Monmouth 1966, p. 87). This puts the reign of Leir's nephew in the middle of the eighth century B.C.E. In Shakespeare's play, the characters' naming of Roman deities and the Fool's statement that he lives before Merlin's time (3.3.95) suggest that Shakespeare did not intend the chronological specificity of Geoffrey of Monmouth's account, and support interpretations of Lear as archetypal and mythic (see R. A. Foakes's comments in Shakespeare 1997a, pp. 30-32). All the gods mentioned in Lear are classical pagan. The OED dates the use of pagan in the sense of "non-Christian" from the 4th century; the earlier classical Latin term referred to a country rustic or, more commonly, to a non-militant, a civilian. The OED offers three potential explanations for the transference of meaning after Christianity: (1) The rural areas were not as quick to receive Christianity as major cities; (2) the Christians considered themselves soldiers of Christ as members of the 'church militant'; (3) the Christians thought of themselves as members of a community, with non-Christians 'rural,' outside this metaphorical city (sv. pagan). 
and labeling are useful yet dangerous human impulses that are never entirely successful. Dichotomies tend toward oversimplification; with varying success, critics have sought two mutually exclusive terms that are together inclusive enough to represent the bulk of criticism in this debate. With regard for the "two camp" tradition on this topic, one might turn to G. Wilson Knight, Paul Siegel, and Greg Maillet to represent the "Christianizers," to William Elton, Roland Mushat Frye, and Joyce Carol Oates to represent the more active resistance to such "Christianizing."

"Shakespeare and the Bible" (and minor variations on this phrase) is probably the most reused title in the history of literary criticism in English; the question of what to do with Shakespeare's biblical allusions throughout his works has generated persistent interest and dispute. ${ }^{23}$ In The Bible in Shakespeare, Hannibal Hamlin summarizes the ongoing critical debate between what William Empson contemptuously called the "neo-Christian school" and its opposers. This "neo-Christian school" is represented by G. Wilson Knight, whose critical approach to Measure for Measure in particular, Hamlin cautions, is problematic in that his identification of biblical allusions is "largely subjective," and "his interpretation of them is skewed by his reading of the play as a Christian allegory." While Hamlin readily agrees Shakespeare works with familiar Christian metaphors, "Knight is not interested in analyzing these passages in depth, considering the dramatic context, or in asking whether, if they do constitute genuine allusions, the effect is straightforward or ironic. Instead, they are meant to support his larger allegorical reading" (Hamlin 2013, p. 68). Yet Hamlin also cautions that Knight's detractors could also be biased: "Studies like Knight's generated considerable ire from critics, like Empson, who were unsympathetic or hostile to Christianity in particular or religion in general, as well as critics who were simply more skeptical about Shakespeare's religious beliefs and the implications of biblical allusions or echoes in the plays" (Hamlin 2013, p. 69).

For Roland Mushat Frye, particularly contemptible was the tendency of the "school of Knight" to find Christ-figures in Shakespeare's plays, "in such weltering profusion as almost to crowd out all other actors from the stage" (Frye 1963, p. 34). "Shakespeare's concerns," Frye argues, are essentially secular, temporal, non-theological" (Frye 1963, p. 7). For "theologizing analyses" of King Lear, Frye's target is Paul Siegel, who in Shakespearean Tragedy and the Elizabethan Compromise argued that "it is the analogy with the crucifixion which is the center of the tragedies and with the resurrection which is the center of the tragi-comedies" (Siegel 1957, p. 231; qtd. in Frye 1963, p. 5). Siegel then read the death of Cordelia as analogous to Jesus' death, and "the redemption of Lear for heaven, a redemption analogous to the redemption of mankind, for which the Son of God had come down to earth" (Siegel 1957, p. 186; qtd. in Frye 1963, p. 37). While some might see Lear's redemption as an earthly change of heart with no cosmic or eternal effect, Siegel makes the opposite concession: "It is for heaven that Lear has been redeemed, not for earth" (Siegel 1957, p. 180). Lear is too old and repents too late to have much earthly impact, yet the all-important transition occurs at his last breath: he dies gaining "the certitude that she is not dead in a binding flash that transfigures him with joy and makes his heart burst in an ecstasy" (Siegel 1957, p. 184). Lear dies believing in Cordelia. Siegel considered the association of Cordelia with Christ "unmistakable, although not crudely explicit" when in Act 4 she is described as one who "redeems nature from the general curse"; Frye reads the same passage and sees "no evidence that Elizabethans [sic] would have regarded Cordelia as a Christ-figure" (Frye 1963, p. 37). ${ }^{24}$ Frye's broader conclusion is that, against "those who now try

23 Note, for example, just a few of the book-length studies: (Eaton 1858; Colton 1888; Burgess 1903; Carter 1905; Coleman 1955; Shaheen 1999; Marx 2000; Hamlin 2013). See also Hamlin's survey of the "Bible and Shakespeare" tradition (pp. 51-59).

24 Frye's demand for supporting evidence from sixteenth-century religious texts is a fair one, yet he neglects to mention that, directly after indicating the analogy between Christ and Cordelia, Siegel points the reader to the Elizabethan homilies for constant adjurations to "follow the pattern of conduct established by Christ" (Siegel 1957, p. 186), and it is rather surprising that a critic credentialed with the extensive theological readings Frye lists in his introduction would deny in the words of Cordelia's Gentleman a recognizable allusion to Christ, one that can be easily supported from the early modern religious texts Frye demands and Siegel must have thought unnecessary to specify. For particular evidence of the allusion as recognizable to Shakespeare's audience, one need look no further than the explication of 1 Corinthians 15 in the Geneva-Tomson Bible or The Order for the Burial of the Dead in The Book of Common Prayer (see note 5 above). Frye would have made a stronger 
to convert his plays into Christian parables," Shakespeare's predominant dramatic concerns are "universally human," "equally accessible to Christians and to the virtuous heathen," and when he did make a character express Christian ideas, he made sure to use "terms which were readily recognizable by the standards of sixteenth-century theology" (Frye 1963, p. 272). For Frye, such terms are not present in the characterization of Cordelia, and Lear remains "a secular drama set in a pre-Christian and explicitly pagan world" (Frye 1963, p. 37).

In King Lear and the Gods, William Elton (among others) followed Frye in declaring the "optimistic Christian interpretation of Lear" as "probably invalid" and dependent on "unhistorical, a priori misreading" (Elton 1988, pp. 336, 337). Rather than painting Cordelia as a Christ figure, Elton assigned the major characters of Lear each a place within categories of pagan thought: Gloucester is the superstitious pagan, Goneril, Regan, and Edmund atheists, and Cordelia and Edgar exemplars of prisca theologia, demonstrating "pre-Christian purity" (Elton 1988, p. 171). Lear himself is "a serious representation of pre-Christian pagan belief of elevated mind and strength" who, over the course of the tragedy, "is shown to develop from pagan belief to disbelief" (Elton 1988, pp. 172, 336). Elton concludes, "(1) no evidence exists to show that Lear arrives finally at 'salvation,' 'regeneration,' or 'redemption,' and (2) the purported benevolent, just, or special providence cannot be shown to be operative" (Elton 1988, p. 336). While the sin-suffering-redemption pattern may seem to progress through the first four acts, "the devastating fifth act shatters, more violently than an earlier apostasy might have done, the foundations of faith itself" (Elton 1988, p. 336). While a "less speculative devout" in the audience might interpret this pagan chaos as preliminary to the triumph of his own religion, "more troubled and sophisticated auditors" could link the attack on heathenism to a "blow for Christianity" in the "unsteady new world of the later Renaissance" (Elton 1988, p. 338).

Similarly, for Joyce Carol Oates, Shakespeare's changes to the Lear story render the ending distinctly not redemptive: "Shakespeare himself invites us to question that ending, by daring to force it out of its natural curve toward redemption." (Oates 1974, p. 24). Neither is it "religious": "Great art usually allows the instinctive life its articulation on a high, aesthetically satisfying plane: In Lear the very life-force itself is denied, and it is impossible to see the work as 'religious' in any way" (Oates 1974, p. 24). It is worth noting, however, that in Oates's reading the question of redemption and religion in this play is bound, as it is for Bradley and "the Christianizers," to the question of what Cordelia can do to save Lear. It is a problem she articulates in Christian terms: "The play is so baffling, so unconvincing, and yet so unforgettable, precisely because there is no conclusion possible at all, given the premises of the problem Shakespeare set himself-that fallen nature somehow engender a being not corrupt and not fallen, a savior. It was an impossible task" (Oates 1974, p. 24).

To Greg Maillet, conversely, the task of saving Lear is not only possible-it is accomplished, even extended to the spectator, the play concluding with a "sustained effort to expand our vision beyond this life, this world of suffering and pain, in order to enable us to see clearly the soul's journey towards eternity" (Maillet 2016, p. 114). The tone of Maillet's theologizing reading is quite assured and evangelical: "If the characters of this play and its audience will but 'look there, look there' (5.3.285) as Lear directs, Shakespeare's drama enacts and thus encourages human souls to commune with the divine life of God that always already allows each individual person to exist" (Maillet 2016, p. 128). While careful to acknowledge repeatedly the compatibility of a Christian perspective and the genuine experience of suffering and grief at the loss of a loved one, Maillet concludes, "A Christian understanding of love thus can and should fundamentally influence one's evaluation of the conclusion of King Lear. It is clear at the end of the play that Cordelia and Lear share a great love, but what is its significance? The moments of death in King Lear are tragic, as beloved characters' earthly lives are over, but Lear's

case against Siegel had he objected to what was done with assumptions drawn from the analogy of Cordelia to Christ, rather than questioning the analogy itself. Later Siegel limited his argument for redemption in King Lear with a "perhaps" and for resurrection in the play to "a suggestion," but he insisted "this suggestion is Shakespeare's, not a product of critics' fancies" (Siegel 1968, pp. 120-21). 
final command, "Look there, look there," does point towards the defeat of death itself, the 'last enemy that shall be destroyed' (1 Cor. 15:26) (Maillet 2016, p. 134). The only Love that truly conquers all is God's. Maillet's approach is sufficiently revealed in the title of his book, Learning to See the Theological Vision of Shakespeare's King Lear; Maillet would have the alert reader or spectator of King Lear at least reach after some eternal beatific vision intimated within the play, if not convert to Christianity.

To be fair, one may find nuanced and qualifying passages in the works of criticism that have served to represent each of these interpretive camps. As Joseph Summers points out, A. C. Bradley is best understood in context; Bradley's consideration of the redemptive potential in Lear is measured and qualified, while the boldest of his interpretive forays are often lifted out of this context for censure by "anti-Bradleyans" (Summers 1980, pp. 74, 77). G. Wilson Knight, so frequently lambasted as the easy target among the "Christianizers," lamented that Frye and "large sections of the literary public had failed to realize what [Knight's] forty years of Shakespearean labour was about" (Knight 1967, p. v); looking back on those forty years in an essay collection, Knight insisted that all along he had striven to show that "Shakespeare differs from orthodox Christianity not by being less, nor alien, but by a greater inclusiveness" (Knight 1967, pp. 24-25). ${ }^{25}$ While Paul Siegel's interpretation of Lear's redemption depends on the protagonist's assumed entrance into heaven, he does acknowledge that "the afterlife of Christian religion acts in [Shakespeare's major tragedies] as an imposing but faintly painted and unobtrusive backdrop for the action," one that "does not become so dominant that the suffering of the good is made to seem unimportant in the light of eternity" (Siegel 1957, pp. 90, 91). Likewise, a key part of Maillet's project is to emphasize that Christian faith in divine providence is compatible with authentic experiences of suffering (Maillet 2016, pp. viii-ix, 114).

On the other side, William Elton deftly handles the various religious elements in Lear: "[T]he threads of the work's central sense merge, unwind, come together and apart, on more than one level. If therefore, among King Lear's thematic preoccupations is belief, we might expect to find confluences and contradictions in belief, perhaps ambiguous, perhaps simultaneous," and that "if Lear is, as many critics hold, Shakespeare's most complexly symphonic work its protagonist might, in all probability, be approached as a microcosm of that complexity" (Elton 1988, p. 172). Such nuance allows Elton to acknowledge Shakespeare writes for a culturally Christian audience, and to grant Christian elements in this pagan play, even if he admits far fewer of them than the critics he opposes. Cordelia is associated with "relevant allusions which, taken in their entirety, form a meaningful pattern of pious and reverent belief," her actions anticipating the higher virtues of faith, hope, and charity" (Elton 1988, pp. 76, 79). Lear is not only a "'good' pagan," he is also "a more complex analog to the Jacobean Christian believer, the spectator of Shakespeare's play" (Elton 1988, p. 173). And while Oates finds the play utterly nonreligious and parenthetically asserts that "Shakespeare's atheism seems unarguable," she does see the play reaching after a substitute for God, dramatizing "the soul's yearning for infinity, the desire of man to reach out to a higher form of himself, if not actually to 'God'" (Oates 1974, p. 28). Similarly, the play provides a species of limited redemption: "In order to complete his soul and be redeemed (in psychological terms: to activate his fullest identity) the hero must unite with the element that seems to oppose him" (Oates 1974, p. 28). Cordelia's opposition does not preserve her father's life, but it does offer insight into "the value of experience, even if that experience is suffering and death itself" (Oates 1974, p. 28). Even Frye, so scathing in his criticism of the "supposedly theological analyses" of the "School of Knight," yet approves of Richmond Noble's thorough study of biblical allusions in Shakespeare, admitting, "While Shakespeare is patently not concerned with theology in any such

25 In a 1928 essay on "The Poet and Immortality," Knight had considered King Lear dark enough, yet pointed to the comforts, not only of death, but of "another life-truth firm and based in eternity: in the mysterious eternity of value; the value of human aspiration and passion, unmoral, timeless, indestructible"; Lear is one step in the sequence of tragedies majestically culminating in Antony and Cleopatra's "vision and revelation of death joyful, immediate, and final" (Knight 1967, p. 45). Knight's "Christianizing" impulse is not so obvious here, as the small comforts of one pagan tragedy are seen in trajectory toward the ecstasies of another. And in his 1964 essay "New Light on the Sonnets," Knight observes that in King Lear, as in Hamlet, Troilus and Cressida, and Macbeth, "nihilism is barely controlled" (Knight 1967, p. 263). 
way as are Spenser, Milton, and Bunyan, his plays do contain more theological allusions than have sometimes been recognized" (Frye 1963, pp. 5, 9). Shakespeare "seems to have known Christian doctrine intimately"; Frye assents: "That Shakespeare was quite literate in Christian theology, and easily conversant in its categories, seems to me indisputably apparent" (Frye 1963, pp. 9, 10).

The question then becomes not whether Shakespeare alludes to the Bible and Christian doctrine but what one should make of such allusions. Hamlin cautions the reader in the process of rejecting "the specious claims of Knight, Siegel, ... and others" not to reject Shakespeare's use of biblical allusion entirely, for "Shakespeare does in fact create 'Christ-figures,' insofar as he uses biblical allusion to suggest comparisons, or, more often, contrasts between certain of his characters and Christ. Cordelia is one such, and so is Lear ..." (Hamlin 2013, p. 71). It is possible, then, that the double occurrence of the word "redeem" in connection with Cordelia serves to present her as a potential Christ figure but also to underscore her limitations in that role. She cannot conquer death, but she can encourage Lear's moral development and his experience of transformative love. ${ }^{26}$ Hamlin reminds us bluntly: "To see Christ-figures everywhere in sixteenth- and seventeenth-century English culture is not a delusion nor the result of a 'neo-Christian' bias. Christ was everywhere, since everyone was (in some sort) Christian, and Christ was the essential model for living and essential to salvation" (Hamlin 2013, p. 71). While noting recent "persuasive arguments for a skeptical or even atheist Shakespeare," Hamlin's summative remark on the history of criticism on Shakespeare and the Bible is that "Shakespeare knew the Bible extremely well, and he alluded to it very frequently in the plays"-and that such allusions "deserve thorough, systematic, critical—and confessionally unbiased—study" (p. 76). ${ }^{27}$

Recently, scholars have attempted to syncretize these interpretive poles, acknowledging the ambiguity of the ending, the potential for redemptive readings, and the limitations of the realization of that potential. ${ }^{28}$ The critical turn toward making qualifications and entertaining ambiguities in Lear may be represented by statements from Joseph Wittreich and Alison Shell. In considering the allusions to biblical apocalypse in King Lear, Wittreich keenly observed that the "apocalyptic framework in King Lear neither discredits a non-Christian, nor credits a Christian reading of the play; and rather than lessening, it complicates the problem of perspective in the play" (Wittreich 1984, p. 124). King Lear

26 For Harold Skulsky, "Cordelia imitates Christ in two primary senses. First, she has resisted strong pressure to blur the distinction between God and Caesar, dignity and price, inward and outward worth .... Second, she embraces a way of life that extends the loyalties of blood and bond to all humanity" (Skulsky 1966, pp. 12, 13). Like Christ, she chooses being over seeming, and she widens the duty of loving one's neighbor to include stranger and enemy (Cf. Matthew 5:44, 22:17-21, 36-40, 23:25-28; Luke 10:26-38; Galatians 3:28).

27 Hamlin's call for confessionally unbiased scholarship may be regarded as a reasonable reaction to a sizeable quantity of writing on Shakespeare not by the serious scholar but by the "religious enthusiast exploiting Shakespeare for his own purposes" (R. W. Zandvoort's phrase appropriated by Elton in King Lear and the Gods, p. 6). The quest for objectivity in criticism might be balanced by the words of Stephen Greenblatt in Hamlet in Purgatory: "I know, in any case, that I am incapable of simply bracketing my own origins; rather, I find myself trying to transform them, most often silently and implicitly, into the love I bring to my work" (Greenblatt 2013, p. 5). Speaking for myself, a confessional Christian raised in a Christian family, teaching at a Christian university where many of my colleagues share a keen interest in early modern theology, I consider myself culturally equipped to discover biblical allusions in early modern literature; given the heated critical controversy regarding what Lear does and does not do with biblical allusions, I also recognize the need to be aware of the temptation to too readily see what may not be there.

28 While in 1979 T. W. Craik speculated that for Richard Burbage there must have been some clarity about the ending in its original performance (Craik 1981, p. 172), Joseph Summers judiciously cautions: “It is easy to go wrong-to push for a kind of clarity and finality that Shakespeare could have provided but surely did not; and the results of such interpretations can be fairly disastrous in attempts to produce the play on the stage or screen: final concentration on the group of survivors watching the soul of Lear ascend to heaven may be even more distracting than a final lingering on a landscape full of corpses and burning desolation-the world as hell" (Summers 1980, p. 79). For Michael Holahan, Lear is indeed transformed in learning to attend and respond to Cordelia's gentle voice. In Lear's final words, "Beholders are asked to see what may not exist, for this is and is not Cordelia" (Holahan 1997, p. 412). Upon hearing Lear's "Look there," Holahan warns, "we run the risk of becoming what we see, of speaking for ourselves the voice that we long to hear. There is, nevertheless, a greater risk: that of refusing sight and of regarding silence as if it means nothing at all" (Holahan 1997, p. 430). For Harold Fisch, "Lear is not redeemed but he sees the phantom of redemption, he hears the echo of a different myth," and the play's "two opposing models of dramatic action, the biblical and the Pagan, are each shadowed by the phantom of the other"; "The result is a work of art that is neither pure tragedy nor pure salvation-history; it testifies rather to the phenomenological dualism that is at the heart of our culture" (Fisch 1999, pp. 148, 149). 
"presents a counter-assertion for each of its assertions" and "draws its life from the conflicts it explores, that even if it does not resolve those conflicts powerfully expresses them and persistently uses them to comment on one another and on the world of which they are a sometimes shivering reflection ... . A criticism faithful to King Lear will put the mind on the stretch and encompass the dynamic of contradiction that the play itself contains" (Wittreich 1984, p. x). For Alison Shell, "part of the play's fascination is that, while inviting both atheistical and Christianized readings, it resists a totalizing explanation" (Shell 2010, p. 186). ${ }^{29}$ She reflects, "Nothing in King Lear, in fact, is incompatible with the Christianity of the place and time it was written. But that being so, why has it so often been read as a play which calls the very existence of God into question? And why, conversely, have the play's redemptive elements been overstressed to an extent which cheapens its irresolvable sadness?" (Shell 2010, p. 194). The questions are well asked.

A sensitive and robust scholarly reading of King Lear will not explain away its ambiguities or its sorrow. Hamlin notes a significant tension between head and heart in audience and reader response to the play:

King Lear is as many faceted a play as has ever been written, and Shakespeare's audience was probably not homogeneous in its response to these interpretive options ... . The closing lines of the play ... urge us to 'Speak what we feel, not what we ought to say' (5.3.323), and this point might be applied to the play's fundamental questions about God's justice and providence. What a good Protestant Christian 'ought to say' in response to King Lear has been voiced by a number of critics, whether Christian, neo-Christian, or historicist. What we may feel, though, is that all such readings are inadequate to the tragic power of Shakespeare's play. No theological argument proves convincing in the face of innocent suffering. (Hamlin 2013, pp. 332-33)

\section{Such was Arthur Kirsch's conclusion in 1988:}

We can spend much time gauging the level of irony in the endings of the tragedies, but when we see or read these great plays we do not construe the endings, we feel them, and what we feel is a paramount sense of suffering and loss. The distinction of King Lear is that the death of Cordelia compounds that feeling and focuses on it. All of us are pagan in our immediate response to dying and death. The final scene of King Lear is a representation-among the most moving in all drama- of the universality of this experience and of its immeasurable pain. (Kirsch 1988, p. 170)

Kirsch's conclusion is moving but not entirely just in implying that only paganism, and not Christianity, can provide the tools to respond authentically and sensitively to suffering. Within Christianity, one might find a robust awareness of and sensitivity to human suffering that is not simply dismissed by a doctrine of divine providence and sovereignty. Since the Protestant Reformation

29 Reading Lear in light of early-seventeenth-century English Calvinist beliefs about divine providence, Shell argues that in the play "the word 'redeem,' with its Christological overtones ... points to the idea that contingency can have a place in an overarching providential scheme" (Shell 2010, p. 193). The comfort of the existentialist-the freedom to choose to continue in the face of apparent absurdity and deep suffering-is not incompatible with the Christian threads presented in Shakespeare's "nuanced understanding of providence" (Shell 2010, p. 193). Shell suggests a playgoer in Shakespeare's day, lacking modern notions of fairness influencing both the "nihilistic and Christian" critical camps, might be less personally concerned with the cosmic situation and more with the protagonist's reaction to it: "For many critics of the last few generations, perhaps the majority of them, King Lear sets out a world where no god alleviates suffering. To an early-modern viewer the play is more likely to have played to fears about one's own imperfection: how, even when the hand of God was manifested, one might not react appropriately to it" (Shell 2010, pp. 96, 195). Shell emphasizes that Lear himself might not act appropriately in his final response to suffering, for his comfort and illumination are only partial: "[T]he fact that Lear remains fixated on his own desires and sorrows suggests that he perceives redemption in a dangerously limited manner, as only operating through an ending that he himself would find happy" (Shell 2010, p. 193). Divine providence is bigger than any one person's idea of happiness - even a king's - but is not this one of the very statements existentialists and individual sufferers find objectionable? It is very human to reject the question "Why seems it so particular with thee?" as an adequate response to personal grief. For an essay on early modern Calvinist notions of Providence influencing Hamlet, see (Lander 2018). 
one version of this Christian understanding of suffering has been called the theology of the cross, and it depends on human humility and divine grace. ${ }^{30}$ This is not far from what Lear experiences in Act 4, scene 7, the reconciliation scene where Cordelia comforts and forgives her father. Lear's humiliation leads to humility, and his suffering mind and body are strengthened with those two great Shakespearean restoratives, forgiveness and sleep. Too well Lear knows the forgiveness is undeserved. To be fair, there is room within paganism for humility and grace, too, and room for believing in life beyond life. The typical pagan is just as unlikely to say "She's dead as earth" as is the Christian, although for different reasons (5.3.259). Such a beautiful reconciliation as Lear experiences with his daughter does not negate his final sorrows, any more than conversion to Christianity or any other faith renders one invulnerable to suffering and mortality. But in what sense might death be a passage to life in this play? The physical "crosses" of Lear's exertions at the end of the play are futile and enfeeble him, even if his ability to kill Cordelia's murderer is wondrous. But what of the psychological or spiritual crosses or exertions of this play? ${ }^{31}$ Does the suffering of Lear improve him in any way? Is the suffering of Cordelia absurd and meaningless, or is this a sacrifice, a result of the hazards of authentic and active love, eventually leading not merely to death but to some ultimate (even if ambiguous and incomplete) redemption? Lear's encounter with death and dying may be pagan, may be Christian. Kirsch is right that it is universal. Here is Harold Skulsky, coming from a rather different argument about Lear from Kirsch's or Hamlin's, and yet reaching a similar conclusion regarding one's appropriate emotional response: "In the midst of this horror, there is great love, and knowledge, and much praise. But to the torment itself, the only decent response is compassion, not hosanna; compassion, bewilderment, and mourning" (Skulsky 1966, p. 17). Whether or not our reading of the play effects a cathartic fear in response to a staged image of existential horror, the call to pity and sensitivity to others pervades the tragedy and extends to the audience. Let us then examine the play more closely. If there is any vision of redemption within King Lear, we must see it feelingly.

\section{3. "No Good Divinity": Ambiguity and Absent Gods in King Lear}

When a maddened Lear and a blinded Gloucester meet at Dover, Lear rails against the flatterers who have encouraged him in his folly. Among other bitter reflections he muses, "They flattered me like a dog and told me I had the white hairs in my beard ere the black ones were there. To say 'ay' and 'no' to everything that I said 'ay' and 'no' to was no good divinity" (4.6.96-100). This is the emendation as found in the Norton Shakespeare and the Arden Shakespeare, and it emphasizes Lear's grief that his fiat was so seldomly challenged (Cordelia's and Kent's remonstrances being notable exceptions). His flatterers' verbal compliance was "no good divinity," not only because flattery ill becomes the theologian or the godly layman, but also because such flattery encouraged Lear to see himself in a divine, not human, position: “Go to, they are not men o'their words. They told me I was everything. "Tis a lie. I am not ague-proof" (4.6.103-5). The First Quarto and Folio texts, however, feature spelling and punctuation variations that permit a different meaning, as rendered, for example, in the Riverside

30 See Luther's Theses 16-21 from the 1518 Heidelberg Disputation in (Grimm and Lehmann 1957, pp. 35-70, esp. p. 53). Of course, human humility and divine grace also have a place in pre-Reformation Christian traditions.

31 The immediate context of Lear's "these same crosses spoil me" relates to sword parry (hence Lear recalls his "good biting falchion" in the previous line (5.3.274-75). I agree with R. A. Foakes's note in the Arden that Lear "refers generally to all his afflictions," and this primary sense of Lear's crosses conforms best with OED sv. cross, definition 10b: "a trouble, vexation, annoyance, misfortune, adversity ... "; and def. 27: "A crossing or thwarting," which cites Much Ado about Nothing 2.2.4: "Any barre, any crosse, any impediment ...." In my reading these senses are not incompatible with definition 10a: "A trial of affliction viewed in its Christian aspect, to be borne for Christ's sake with Christian patience; often in to bear, take (up) one's cross, with reference to Matt. x.38, xiv.24, etc." This use of the word is found as early as Wycliffe's translation of the Bible and was common in early modern religious writings. Here is the 1595 Geneva-Tomson translation of Matthew 10:38-39: "And he that taketh not his crosse, and followeth after me, is not worthy of me. He that will finde his life; shall lose it: And he that loseth his life for my sake, shall finde it." (Geneva-Tomson Bible 1595). Tomson's marginal gloss for verse 39 explains, "They are sayd to finde their life, which deliver it out of danger: and this is spoken after the opinion of the people which think them cleane lost that die, because they thinke not of the life to come." See note 34 below for Richmond Noble's argument for Shakespeare's use of the Geneva-Tomson Bible and its marginal notes. 
Shakespeare: “To say 'ay' and 'no' to everything that I said! 'Ay,' and 'no,' too, was no good divinity."32 This rendering shifts Lear's emphasis from exclaiming against his flatterers' superficial compliance, to exclaiming against their readiness both to assert and to deny at once any statement Lear might make. Such flatterers are like the equivocator Macbeth's porter welcomes to hell, their sophistry and seemingly pious rationalizations reminiscent of the unhelpful theological mazes that medieval scholasticism was known for in Shakespeare's day (cf. Macbeth 2.3.7-9). ${ }^{33}$ In his own mad search for answers, Lear stumbles upon contradictions and circumlocutions; little does he anticipate his imminent restoration to sanity through the plain, emphatic, and sincere speech and actions of Cordelia.

His reference to the ayes and noes used in bad theology bears a biblical allusion; most modern editions point the reader either to Matthew 5:36-37 or to its echo in James 5:12: "Let your yea, be yea, and your nay, nay." ${ }^{34}$ Lear's reference to white and black hairs (Lear 4.6.97-99) particularly refers to Jesus' words in the Matthew passage: "Neither shalt thou swear by thine head, because thou canst not make one haire white or blacke." In their own contexts, both the Matthew and James passages are concerned with swearing-not with equivocation or flattery. Shakespeare's use of biblical allusions adds ambiguity and further layers of potential meaning here. His pre-Christian king echoes a New Testament allusion, applying it to a context quite different from that of its source, and conveying a moral observation quite different from the correlative concerns of Matthew or of James. Yet the opposition of hypocrisy is certainly not foreign to the gospel of Matthew, and in the Tragedy of Lear Kent twice implies the reckless futility of swearing by the gods. In a play full of textual variants and interpretive ambiguities, the master playwright of ambiguity himself has his tragic protagonist rail against not only flattery, but also equivocation and conflicting, sophisticated statements.

There is no need, of course, to equate Lear's concerns with Shakespeare's own, nor to hold Shakespeare's play to its protagonist's standards for "good divinity." The law of noncontradiction does not apply here; within the golden world of poetry, the realm of Lear may be both pagan and Christian. Layers of new and old meanings and the interpretive ambiguities the playwright courts add to the richness of his language. Cordelia may be presented as a model of pure plainness, but Shakespeare is not. Beyond the basic step of distinguishing character from author, the key difference between the doublespeak of Lear's flatterers and the equivocations of Shakespeare's pen may lie in the heart of the communicator. Theirs is motivated by selfish aggrandizement and exploitation of weakness and folly; the poet's is a gift of rich, if not infinite, variety-food for heart and mind that strengthens the receiver, through catharsis if not through the comforting introduction of hope. In King Lear, nowhere is this rich variety more evident than in the investigation of the play's own theological layers.

Shakespeare's characters in Lear entertain varying and competing assumptions about the role of gods, fate, and astral influences in relation to human suffering. None of these assumptions is

32 The Arden Shakespeare records the early textual variants of "everything ... was" thus: euery thing I saide, I and no toe, was Q; all I saide: I and no too was Q2; euery thing that I said: I, and no too, was F (Shakespeare 1997a, ed. Foakes, p. 334). Emendations are thus necessary in editions seeking the clarity of modernized spelling and punctuation.

33 For an intriguing argument that Macbeth would have intellectually, morally, and spiritually benefited from the type of equivocation associated with early modern Roman Catholic casuistic reasoning, attentive to subtleties, open to possibilities, and resistant to oversimplification and determinism associated with Protestant theology, see (Curran 2018). For key examples of early modern reactions against scholasticism, one may turn to the fifth rule of Erasmus's 1503 Enchiridion (Erasmus 1983, esp. pp. 63-64), Erasmus's 1511 Praise of Folly and its augmentations (see esp. Erasmus 1993, pp. 86-95, but see also the caveat in A. H. T. Levi's introduction, pp. xx-xxi); Thomas More's Utopia (1516, published in English in 1551; see esp. More 2003, pp. 120-24) and More's October 21, 1515 letter to Maarten van Dorp (Nauert 1998); Philip Melanchthon's 1518 inaugural address to the faculty of the University of Wittenberg (see Christian Preus's introduction in Melanchthon 2014, pp. 11-12), and John Webster's 1654 Academarium Examen.

34 Except where otherwise noted, quotations from the Bible are taken from a 1595 Geneva Bible with Laurence Tomson's revisions of the text and annotations for the New Testament. I have emended frequently interchanged letters (i/j, u/v) to conform to modern usage. The choice of a Geneva-Tomson Bible follows Richmond Noble's extensive work in identifying the versions Shakespeare used, which concludes that "the evidence is in favour of Shakespeare's possession of a Genevan Old Testament bound up with a Tomson New Testament, and there is also an indication that he may have been influenced by a Tomson marginal note" (Noble 1970, p. 58; cf. p. 8). This revision of the Genevan Bible with Tomson's extended notes was "the most popular Bible of the day" (Noble 1970, p. 92). Shakespeare's use of the Bishop's Bible and the Book of Common Prayer as well as the possibility of other versions of the Bible has also been established by Noble (1970, pp. 58-89). 
established as true or dominant to the exclusion of all others within the play. For example, Edmund scoffs at Gloucester's attribution of political and social unrest to lunar and solar eclipses, and he scorns the general shrugging off of human responsibility as if all were subject to the "enforced obedience of planetary influence" or a "divine thrusting on" (1.2.104-6, 118-26). Edmund fails, however, to disprove this influence or thrust, for he chooses the path of villainy, one that merely supports society's expectations and his horoscope's prognosis, both based on something outside of his control: the circumstances of his birth. Noting the chasm separating the way Lear's two eldest and his youngest have treated their father, Kent concludes, "It is the stars, / The stars above us govern our conditions, / Else one self mate and make could not beget such different issues" (4.3.33-36). And Lear's first words of anger against Cordelia make it clear that in this pagan world, the celestial bodies to which Gloucester and Kent refer are metonyms for the gods themselves: "For by the sacred radiance of the sun, / The mysteries of Hecate and the night, By all the operation of the orbs / From whom we do exist and cease to be, / Here I disclaim all my paternal care ... " (1.1.110-13). For Gloucester, Kent, and Lear, the stars are gods, and astrology is divinity. Edmund scoffs at this, but his villainy does not refute it. Only his attempt to do "some good" in his final moments, to save Lear and Cordelia from the death he has plotted for them, bears some evidence against the influence of the stars. Cordelia is hanged, and Lear, who kills her murderer, does not improve his lot a whit based on Edmund's late good intentions. If any good is accomplished by Edmund's last effort, it is found in the heart, not the stars.

The play's references to fate and fortune are similarly complex. A maddened Lear on the heath makes the single direct reference to fate in this play: "Now all the plagues that in the pendulous air / Hang fated o'er men's faults light on thy daughters" (3.4.66-67); but this is joined with a curse and with reference to "men's faults," thus muddling ideas of fate with those of human control and responsibility (3.4.66-67). The references to Fortune are many, and most often unpromising; it is as if being "sick in fortune" (a condition Edmund describes as "often the surfeits of our own behavior") is the most natural relationship one might have with the goddess in this play (1.2.107-8). Edmund invokes "Briefness and fortune" in his plot to sever the bond between his father and his brother (2.1.18). The Fool calls Fortune "that arrant whore" who "Ne'er turns the key to the poor" (2.2.242-43). A maddened Lear, misinterpreting the approach of one of Cordelia's Gentlemen as hostile, considers himself "The natural fool of fortune" (4.6.87).

Yet Kent and Edgar believe Fortune has an uncanny habit of raising the destitute. Kent in the stocks bids "Fortune, good night: Smile once more; turn thy wheel" (2.2.171); Edgar offers himself this solace: "To be worst, / The lowest and most dejected thing of fortune, / Stands still in esperance, lives not in fear. / The lamentable change is from the best, / The worst returns to laughter" (4.1.2-6). With such optimism Edgar can say to Albany, "Fortune love you" (5.1.47). And Cordelia, self-assured in her own integrity and powers of endurance, feels Fortune's blows only as they affect her father: "We are not the first / Who with best meaning have incurred the worst. / For thee, oppressed King, I am cast down; / Myself could else outfrown false fortune's frown" (5.3.3-6). Fortune is indeed "false" to many in this play. Cordelia may be bested by the Stoic, but in this tragedy pity for others is a higher calling than stoic resolve. ${ }^{35}$

The ambiguous roles of fate, fortune, and heavenly influence are further complicated by the simple fact that the frequently invoked gods of this play never show up. Considered alone, this absence does not distinguish Shakespeare's Lear from most of his other plays-although the appearances of Hecate in Macbeth, Hymen in As You Like It, Diana in Pericles, and Jupiter in Cymbeline (to say nothing of ghosts, spirits, and fairies) are reminders that he could have included gods in Lear as well,

35 Oscar James Campbell argues that Lear is a supremely un-Stoic man who learns Stoic insights but is ultimately redeemed by the "healing power of Christian love" through Cordelia's example (Campbell 1948, pp. 100, 106). For a concise examination of early modern theological perspectives on faith in Providence as the appropriate Christian replacement of pagan resignation to Fortune, and for a reading of Christian pity and mercy surpassing a "religion of paganized self-sufficiency" in Shakespeare's The Tempest, see (Urban 2019, esp. pp. 7-14). 
at least as speaking apparitions, had they served his dramatic purposes. Lear's characters swear by the gods, allege their malevolence, absence, apathy, or justice, or insist that the gods assist them in cursing others. In the opening scene, Lear's enraged "Now by Apollo-" is promptly met with Kent's "Now, by Apollo, King, / Thou swear'st thy gods in vain" (1.1.161-62). ${ }^{36}$ The superstitious, sightless Gloucester assumes divine malevolence: "As flies to wanton boys, are we to the gods; they kill us for their sport" (4.1.38-39). The moralizing Albany, learning of Cornwall's death after the blinding of Gloucester, assumes divine retribution: "This shows you are above, / You justicers" (4.2.79-80). But, of course, the death of Cornwall has a human explanation. His servant opposed him in defense of Gloucester. The earl's cry, "Give me some help!-O cruel! O you gods!" is otherwise met with dei absconditi.

In the opening scene, the King of France ponders how divine silence can inspire new human bonds: "Gods, gods! 'Tis strange that from their cold'st neglect / My love should kindle to inflamed respect" (1.1.256-57). In context, this "inflamed respect" is clearly for Cordelia, who inspires in France a stronger ardor after he learns that Lear has disowned and disinherited her for no good reason. "She is herself a dowry," France observes, and he seeks to ease her departure from Albion and her family with this assurance: "Thou losest here a better where to find" $(1.1 .263,243)$. For a Jacobean audience, one of the many uncomfortable sorrows of this tragedy is that France, not England, becomes Cordelia's promised land, her superior kingdom, her "better where." Spectators resisting such an interpretation might see France's words as more symbolic or spiritual, intimating a familiar biblical allusion: "And [Jesus] sayd unto them, Verely I say unto you, there is no man that hath left house, or parents, or brethren, or wife, or children for the kingdome of Gods sake, Which shal not receive much more in this world, and in the world to come life everlasting" (Luke 18:29-30). The "better where" may allude to some kingdom of the heart, the spiritual realm of personal integrity Cordelia may keep intact even as Lear's disownment of her severs the heart of his own kingdom.

Over the course of the tragedy, Cordelia becomes a central figure of innocent suffering, but she also becomes the figurative heart of the play's thread of hope in two major senses. She is the representative of both integrity and compassion, of both truth and love. She is first a model of inner strength and substance, of the truth that Shakespeare consistently wants to find in beauty. Hers was to be the middle portion of the kingdom, and her governance its core strength. Her refusal to play the game of flattery is essentially a sign of her awareness of the value of her personal integrity in comparison with the externals of territory and state. But more importantly, and to effects that will be explored in greater depth in the concluding sections of this essay, Cordelia is a model of love that expresses itself through compassion and sacrifice. Her words and actions on behalf of her father in Acts 4 and 5 contextualize and soften the stubbornness and insensitivity that may be read into her refusal in Act 1 to gratify an aged father's ear. While this refusal too may be motivated by love, it is her later return to, forgiveness of, and fighting for Lear that make the compassionate aspect of Cordelia's heart unmistakable. Her intervention, not the gods', brings new life to Lear, making Lear's world not only liveable, but joyous. Cordelia's example teaches Lear to value the integrity of the inner self over the accumulation of external accommodations, and to treasure her genuine love and compassion over anything her sisters could say to humor him, or any retinue, regal garb, or courtly ritual that might preserve his accustomed self-regard. The path to learning from her example, however, involves first

36 Similarly, in Act 2 Lear's "By Jupiter I swear no" can do nothing to change the fact that his daughter Regan and her husband have put Kent in the stocks; again Lear's passionate swearing by the god is met with Kent's dry rebuttal: "By Juno, I swear ay" (2.2.211-12). Kent's choice of a lesser deity is pointedly inconsequential if neither god listens; it cannot be blasphemy if neither god exists. This returns us to Lear 4.6.96-100 and the allusion to Matthew 5:36-37, for Kent's rejoinders are a sarcastic version of "Let your communication be Yea, yea: Nay, nay." In the biblical source, the reasons Jesus gives for not swearing are associated with God's sovereignty and connection to the world: "Sweare not at all, neither by heaven, for it is the throne of God: Nor yet by the earth, for it is his footstoole: neither by Hierusalem: for it is the citie of the great King" (vv. 34-35). By contrast, Kent's indirect reproof of Lear's swearing by the gods comes from the unsettling thought that such invocations are "in vain." Lear still needs to see better as he swears by the God of sight; his swearing by the king of the gods in disbelief that Regan and Cornwall ignominiously put his servant in the stocks does not change that it is so. 
facing the fact that he wronged her, and then not letting his conviction of wrongdoing be diminished by that other fact-that he himself was wronged. His acute suffering on the heath, which could lead him outside of his mind's storm toward repentance and compassion, is in danger of being eclipsed by his acute indignation at the injustice of daughters or gods.

Thus, many readings of Lear emphasize the turn from disappointing metaphysical contemplations to the proactive ethical—from frustration about unresolved questions about divine justice, benevolence, and existence to a determination to do one's part to help one's fellow humans. This is advanced by a few transformative moments where once-empowered characters learn in their misery to pity and help the unfortunate. When Lear turns to consider the "houseless heads," "unfed sides," and "looped and windowed raggedness" of the poor, he implicates himself- "O, I have ta'en / too little care of this" - and then calls on the pompous to "shake the superflux to [the poor] / And show the heavens more just" (3.4.30-33,35-36). It is up to humanity to make the gods look good. The current trend in interpreting this passage is to focus on shaking the superflux rather than showing the heavens more just-on the economic rather than the theological implications-but of course they go hand in hand. Lear's "superflux" speech can be performed as a prayer; it begins with Lear ushering the Fool into shelter and then announcing, "I'll pray, and then I'll sleep," and it has become customary for actors to kneel through the speech itself. ${ }^{37}$ This kneeling and prayer could be perceived as indicative of Lear's newfound humility and religious contrition, but conversely it might serve to emphasize the substitution of the empathetic wealthy for the gods above. The addressees of this prayer are not the gods but first the "poor naked wretches," who receive Lear's sympathy, and then "pomp" or the rich, who might well receive his sermon $(3.4 .29,33)$. The key moments of Lear's own moral progress are with the Fool in the storm, when Lear learns sympathy-" Art cold? / I am cold myself ... . Poor fool and knave, I have one part in my heart / That's sorry yet for thee" $(3.2 .68-69,72-73)$-and then acts in kindness: "In boy, go first" (3.4.26). Russell Fraser argues that these four monosyllables mark the "hinge of the play," the moment when the downward path of Lear's physical fate touches the upward path of his spiritual or mental progress (Shakespeare 1998, p. lxiv). Gielgud once stated, "You have to decide from the outset whether Lear is a great man who loses his position, or that he acquires greatness and wisdom through suffering" (qtd. in Croall 2015, p. 24). Those who see the chiastic structure Fraser describes find no dilemma.

Fraser also sees this as a Marxist moment: Here is "Lear the Socialist, got up in a red shirt" (Shakespeare 1998, p. lxiv). So has Cicely Berry, Director of Voice at the Royal Shakespeare Company: "I think King Lear is probably the greatest play ever written; I am sure I am not alone in this. But to me it is also a great Marxist play ... . I believe Lear goes on a journey from first being a ruler of a kingdom, then being rejected by his daughters, through madness on the heath, to finally realizing that he is but a man-like any other-and that he has not fulfilled his duty as a man (Carson 2013, p. 59). Fair enough-but the "Marxist" duty Lear learns on the heath is not separable from religion, from the aim to "show the heavens more just." It resonates with the second of the two summative commandments Jesus proclaimed: "Love your neighbor as yourself." Lear's new ability to treat others as he would want to be treated is not motivated by pious zeal, but neither does it indicate a rejection of the gods with all his heart, soul, mind, and strength. The move from pity to purpose, from humane feeling to humanitarian action, even if motivated by the gods' silence, is not itself proof of Lear's world being nonreligious. ${ }^{38}$

Like Lear, Gloucester turns from importuning the deaf heavens to feeling intense personal suffering, to performing a simple act of compassion, to praying for more generalized action. Preparing for suicide, Gloucester sermonizes on altruism, which he models with a bequest to the "naked fellow" he does not recognize as his own disinherited son Edgar:

37 See note for 3.4.28 in the Arden edition (Shakespeare 1997a, p. 273).

38 David Beauregard goes further, seeing in King Lear an "overall theological principle ... that providential governance manifests itself through the mediation of virtuous human beings" (Beauregard 2008, p. 211). 
Here, take this purse, thou whom the heavens' plagues

Have humbled to all strokes. That I am wretched

Makes thee the happier. Heavens deal so still!

Let the superfluous and lust-dieted man

That slaves your ordinance, that will not see

Because he does not feel, feel your powers quickly:

So distribution should undo excess

And each man have enough. (4.1.67-74)

Here Gloucester, like Lear, desires to see divine justice, even though he implicates himself. Fitting his own description of the "superfluous and lust-dieted man," Gloucester despairs of receiving any kindness from the heavens; yet he sees cosmic justice at work, inspiring him to bestow what little kindness he can upon poor Tom. ${ }^{39}$ As in Lear's speech on the poor, feeling is an important step preceding action, but here the requested feeling is not humane empathy but a sense of divine power. This is fitting for Gloucester's character, for he has ever drawn connections between heavenly influence and earthly events. For Gloucester, it is a sense of the gods' powerful presence, rather than their absence, that spurs fear or generosity. As editors and critics have noted, behind Gloucester's reference to a divine "ordinance" are biblical injunctions: Mark 10:21, "Go and sell all that thou hast, and give to the poor, and thou shalt have treasure in heaven" and the 1560 Geneva Bible's gloss (The Geneva Bible 1560) on the parable of the rich man and Lazarus in Luke 16.19-31: "by this storie is declared what punishment thei shal have, which live deliciously \& neglect the poore." 40 The Tomson gloss for the same story also emphasizes the rich man's manner of dress: "very gorgeously and sumptuously: for purple garments were costly, and this fine linen which was a kinde of linen that came out of Achaia, was as deare as gold"; such a gloss connects the parable to Lear's concerns with gorgeous, costly garments (especially at 2.2.456-59 and 3.6.75-78). As with Lear, Gloucester has lived "deliciously," but, as with Lear, Act 4 grants him a fresh opportunity, where Edgar's staged miracle on the "Dover cliffs" reconciles Gloucester to life and to the gods. No longer the "wanton boys" who kill for sport, the "ever gentle gods" may be petitioned for strength against despair (4.6.213-15).

There is much one might say about the gods of Lear, even though they never show up. The grounds for any argument on this topic are unstable, but the debate itself is inescapable and pervasive. In this matter, as others, we may hear the Fool's challenge: "Can you make no use of nothing, nuncle?" (1.4.128-29). For what sets the play in motion but Cordelia's own argument from silence, and the disruptive challenge that something significant—whether bounty or disaster-might indeed come of "nothing"?

\section{Lear Unbound: The Pagan and the Christian in King Lear}

The strongest arguments for the godlessness and devastation of Lear's world point to the play's ending, and yet that ending also contains evidence used in the strongest arguments for that world glimpsing the hope of redemption as presented in Christianity. The choices Shakespeare makes in reworking his historical sources suggest deliberate addition of both pagan and Christian material, and of both bleak and hopeful chords.

Notably, Shakespeare ignores the restorative ending of his source texts. In Geoffrey of Monmouth's History of the Kings of Britain, Holinshed's Chronicles, Spenser's Faerie Queene, Higgins's Mirror for

39 Gloucester's reputation for being "lust-dieted" is apparent in his ungentlemanly jests about Edmund's conception in the opening scene, in the Fool's reference to him as an old lecher (3.4.110), and in Edgar's assumption that Gloucester's blindness is the consequence of his adultery (5.3.168-71).

40 See notes for 4.1.67 in the Arden edition of King Lear edited by R. A. Foakes (Shakespeare 1997a, p. 309); cf. (Kronenfeld 1992, esp. pp. 763, 774). 
Magistrates, and the anonymous True Chronicle History of King Leir, the Cordelia and Lear characters emerge victorious in battle, and the king's authority is restored for him to deliver to or bequeath on the deserving. In the 1605 Leir play particularly, the restorative end is associated with pious statements and pat moralizing. The whole play is set in an explicitly Christian environment, where Leir foolishly calls his eldest daughters "the kindest Gyrles in Christendome." ${ }^{11}$ William Elton's assessment of it is fair: "Divine and poetic justice rule all; the anonymous play never questions them or allows them to be questioned, and the work ceaselessly drums its pious message" (Elton 1988, p. 70). By contrast, Shakespeare's play expunges the heavy didacticism of the Leir play and reverts to the pagan setting of Geoffrey of Monmouth's account.

Nevertheless, Shakespeare's Lear rejects the eventual suicide of Cordelia as presented in Geoffrey of Monmouth's and Holinshed's accounts. According to Geoffrey, after Lear's death Cordelia rules peacefully for five years until her nephews, "indignant at the fact that Britain was subjected to the rule of a woman," rose in rebellion, laid waste the land, and ultimately conquered Cordelia in battle and imprisoned her. Geoffrey has Cordelia die in despair: "There she grieved more and more over the loss of her kingdom and eventually she killed herself" (Geoffrey of Monmouth 1966, p. 87). Holinshed describes her suicide as a heroic pagan action in the line of Cato the Younger: "being a woman of a manlie courage, and despairing to recover libertie, there she slue hirselfe" (Holinshed 1587, vol. 2, p. 13). Shakespeare acknowledges the story of Cordelia's suicide through deliberate revision when he has Edmund plot to make the murder of Cordelia look like a suicide (5.3.250-53). This provides at once an explanation and a dismissal of the legend for his own purposes-ones that conform to the theology of suicide acceptable to his 17th-century Christian audience. For the social and religious consequences of suicide in a Christian context in Shakespeare, one need look no further than the debate over the death and funeral rites of Ophelia in Hamlet. Elsewhere, of course, Shakespeare was comfortable with poetic ecstasies adorning the suicides of Christian and pagan lovers, from Romeo and Juliet to Antony and Cleopatra. But, as R. W. Chambers has argued in an influential essay, to have Cordelia take her own life in despair would compromise her position as Christ-figure and model of Christian virtue (Chambers 1940, pp. 18-24). Had an unrepentant Edmund succeeded in staging her suicide convincingly, the result would have been the doubly villainous effect of murdering both Cordelia and her reputation (at least for Shakespeare's Jacobean audience). Instead, Edmund lives long enough to confess his plot, and Lear survives to reveal and avenge the murder. The intentional reversion from the Christian to a pagan setting is paired with an intentional revision of the early accounts of Cordelia's death by suicide to one acceptable for a Christ-figure to an early modern Christian audience. Shakespeare's further choice of Cordelia dying by being hanged rather than slain by the sword corresponds with Spenser's account against those of Geoffrey of Monmouth, Holinshed, etc. (Spenser 1987, p. 336), and further colors the presentation of Cordelia as a Christ figure (Campbell 1948, p. 107; Guilfoyle 1989, p. 62). Collapsing the story of Cordelia's death into the narrative of Lear's last moments of life is more than dramatic economy-it serves as one further way Shakespeare pins audience perception of the fate of Lear on the life or death of Cordelia, perhaps not unlike the way the whole of Christian faith is pinned on the doctrine of the resurrection. ${ }^{42}$ Neither romance survivor nor stoic suicide, Shakespeare's Cordelia remains a victim, and potentially a martyr, a sacrificial lamb, whose death—and whose influence beyond her death—bears religious intonations.

While William Elton concludes that "Lear, in Shakespeare's hands, becomes a paganized version of a Christian play," it is more accurate to say that Shakespeare's play retells the legend with sensitivity to the problem of evil, the question of divine (in)justice, and the troubled demand for eschatological resolution. This makes Lear a far better play, and one could argue, even a far closer example of

41 The True Chronicle History of King Leir was entered into the Stationers' Register in 1594 and published in 1605. It is widely considered to be one of Shakespeare's most important sources for his own version of the Lear tale. See (Stern 2003).

42 For this, one may turn again to 1 Corinthians 15 (esp. v. 14) and its prominence in the early modern English Protestant mind, as captured in the Geneva-Tomson marginal notes and the Order for the Burial of the Dead (note 5 above). 
a "Christian" one than the moralizing and neatly resolved Leir play. ${ }^{43} \mathrm{~J}$. C. Maxwell has said as much: Lear is "a Christian play about a pagan world" (Maxwell 1950, p. 142). As Grace Tiffany explains, Shakespeare "expressed Christian ideas through pagan situations throughout his entire career"; she also indicates "Shakespeare's career-long pattern of allusions to pre-Christian deities and devotional practices," adding that in "King Lear, and many other pre-1606 plays, Shakespeare accommodates references to pagan practices and beliefs to a dominant Christian perspective which is always powerfully present, if at times, only subtly alluded to" (Tiffany 2018, p. 1). ${ }^{44}$

The greatest of Christian ideas Shakespeare works with is the resurrection. For Sean Benson, "The sense of a resurrection or quasi-resurrection having taken place is a recurrent motif in Shakespeare's comedies and romances, while the countervailing frustration of a failed resurrection is a prominent feature in a number of his tragedies.... Even his plays set in pagan worlds do not avoid the impress of the Resurrection; Shakespeare in fact cultivates the anachronism, yoking the pagan horror at the idea of resurrection to a beatific vision of the joy resurrection might bring" (Benson 2009, pp. 1-2). Benson firmly places Lear in the "quasi-resurrection" category, given the demands of tragedy (Benson 2009, p. 121). Nonetheless, lines with "biblical resonance ... increasingly dot the play's verbal landscape," and as these strands are interwoven "for aesthetic purposes, not didactic religious ends," Shakespeare "opens the pagan play to the illumination of Christian revelation, whether he personally considered it truth or otherwise" (Benson 2009, pp. 104, 105). Naseeb Shaheen notes that "Leir contains some thirty clear biblical references, thirteen possible references or passages with strong biblical echoes, and many religious images. Shakespeare borrowed none of Leir's references. In a few instances ... Shakespeare's references to scripture may have been suggested by a phrase or a parallel situation in the old play. But for the most part, Shakespeare's biblical references are his own" (Shaheen 1999, pp. 604-5). With this in mind, a closer investigation of a few such instances of biblical resonance may prove fruitful.

It is often observed that Shakespeare's Tragedy of King Lear shares themes with the Book of Job. Both texts feature the intense suffering of the protagonist, a crisis of existence and of theodicy, fear of Nature and the Divine, a climactic storm, and deeply significant yet troubling and debatable conclusions. When Lear claims, "I will be the pattern of all patience, / I will say nothing" (3.2.37-38), he is inserting himself into a role conventionally assigned to the biblical Job. To be sure, neither Lear nor the biblical Job is "the pattern of all patience." Job endures much but is not silent about his undeserved suffering. Lear is less so, as he exclaims against the gods in the storm without provoking a divine response to which he might listen. Job repeatedly attests his innocence and integrity (27:5-6; 29:14, 32:1) but ultimately submits to God's inscrutable wisdom and power: "therefore have I spoken that I understode not, even things too wonderfull for me, and which I knew not ... . Therefore I abhorre my selfe, and repent in dust and ashes" (Job 42:3,6). Lear protests in his rage, "I am a man / More sinned against than sinning," but he later implores, "I am a very foolish, fond old man ... Pray you now, forget and forgive; I am old and foolish" (3.2.59-60; 4.7.60, 83-84). For those reading Lear as potentially redemptive, a further parallel may be visible in Job 19:25; a passage that for many Christians connects the Hebrew Bible with the message of the gospel and the doctrine of the resurrection of the body: "For I am sure that my redeemer liveth, and he shall stand the last on the earth. And though after my skinne wormes destroy this body, yet shall I see God in my flesh." The Geneva gloss makes the

43 So also Maillet argues, with a cue from Matthew 10:8, "it should be no surprise that the 'clearest gods' of King Lear, if in some sense they represent Christian divinity, similarly do not protect the major characters from great suffering. If this tragedy is avoided, as in Tate, this essential Christian meaning is lost" (Maillet 2016, p. 114). The position may be contrasted with Beauregard's argument that "a significant reason for Shakespeare's de-Christianizing of the old play is precisely that a pagan setting heightens the mystery and the tragedy, whereas explicit Christian themes of forgiveness, redemption, and a loving God would clearly weaken the tragic effect" (Beauregard 2008, p. 204).

44 In England in the last half of the first decade of the seventeenth century, there were pragmatic as well as aesthetic reasons for subtlety: The 1606 Act in Parliament "to Restraine abuses of Players" imposed a fine for naming God, Jesus Christ, the Holy Spirit, or the Trinity on stage; even if laxly enforced, the law accounts for "Shakespeare's marked post-1606 turn to what were at least superficially pagan worlds" (Tiffany 2018, p. 1). 
connection explicit: "Herein Job declareth plainely that he had a full hope that both the soule and body should enjoy the presence of God in the last resurrection." The passage is one of four scripture readings opening the Order for the Burial of the Dead in the Book of Common Prayer, and thus certainly recognizable in early modern England.

Of course, there are fundamental differences between the two texts. In the book of Job, the reader is given background information regarding the divine testing of Job and the reasons behind it, even if Job is never given this context from which he might better understand his suffering; in Lear, the gods are invoked, feared, and cursed, but neither character nor audience receives any solid evidence of their operations or even their existence within the world of the play. In the book of Job, God speaks in the storm; in Shakespeare's storm on the heath, Lear is the one speaking, and he cannot even be assured that he troubles deaf heaven with his bootless cries. Instead of divine affirmation of the righteousness of the human protagonist (cf. Job 1:8), the play is clear that Lear's folly is as good a cause as any for much of his suffering, even if he is "a man more sinned against than sinning." When Lear does bend in shame and repentance, it is in the restorative presence of Cordelia, rather than at the awesome display of divine creative power. Lear ends with the deaths of Lear and his irreplaceable Cordelia; in the coda to the Book of Job the patriarch enjoys another 140 years of life with new livestock and children enumerated as seemingly fungible and symbolic indicators of his replenished wealth. Shakespeare's refusal of such pat closing comforts can be read as a rejection of the Job coda's resolution as well as a rejection of the "Christianizing," moralizing sentiments of the Leir play. Despite Job's coda, the major parallels are strong, and the comparison "has become a critical commonplace," accepted and examined from different critical perspectives (Hamlin, p. 306). ${ }^{45}$ At their core, both Job and Lear masterfully explore the question of what to make of human suffering, especially when one believes it is disproportionate with what one deserves.

Similar to the question of divine justice working in the midst of intense suffering as found in the Book of Job, the question of whether biblical apocalypse, with its horrors as well as its revelations, might provide a viable "big picture" of the human story, informs King Lear. Joseph Wittreich has written extensively on the apocalyptic references in King Lear, arguing for a Christian undercurrent supporting the pagan play through such references. Pointing out that the title page draws attention to the liturgical context of its first known performance (on St. Stephen's Day) and associating St. Stephen with the charity that characterizes Cordelia, Wittreich argues that "Christianity, thrust on to the margins of the play world by its title page but never silenced, reasserts itself as an ethical nucleus in the play's coda where we are brought to the recognition, so finely formulated in The Tempest, that 'The rarer action is / In virtue then in vengeance' (V.i.27-28)" (Wittreich 1984, p. 27). Wittreich's examination of Shakespeare's biblical influence focuses on the prophetic passages in the Book of Daniel, on Apocalypse (the Book of Revelation), and on early modern commentary on those sections of scripture. In Shakespeare's play, Gloucester's early fears of cosmic, terrestrial, and familial rupture (1.2.103-114), Lear's cries in the storm (3.2.1-9), and in the final scene Kent's question, "Is this the promised end?" with Edgar's addition, "Or image of that horror?" are at the heart of the issue (5.3.261-62). Literally meaning "uncovering," the theme of apocalypse is supported by the motif of clothing and nakedness, and thus to that associated pair of opposites, foolishness and wisdom. Wittreich asserts, "The apocalypse in King Lear is a mind-transforming event that culminates in a king's redemption," but he emphasizes the limitations of Lear's belated discovery of wisdom:

[The play's] universe allows for no more than the resurrection of the spirit in this life; and this in itself is unhinging. There is a first resurrection that portrays man's release from spiritual

45 Hannibal Hamlin's chapter on Lear in The Bible in Shakespeare is entirely devoted to the play's resonances with the book of Job, and he works with a range of scholarship on the subject. Key arguments may be found in (Holloway 1961, p. 85; Elton 1988, pp. 20-30, 68; Colie 1974, pp. 117-44; Muir 1984, pp. 289-90; Milward 1987, pp. 173-80; Bloom 1989, p. 19; and Marx 2000, pp. 59-78). Hamlin also points to (Rosenberg 1966), which associates the neo-Christian critics with Job's friends, "wishful-thinking but naïve" (Hamlin 2013, p. 307). 
darkness, as out of the grave; but whatever measure of self-understanding is achieved in that resurrection, man is still subject to the deceptions of this world. Nowhere is the irony of this predicament dramatized more poignantly than in the final scene of Lear where a regenerated man desists from his declaiming against the universe: 'Look on her, look, her lips, / Look there, look there!' (V.iii.310-11). (Wittreich 1984, pp. 33, 119-20)

Wittreich's strongest turn is ethical and earth bound:

Shakespeare's strategy is to use apocalypse against itself, not to deny it as a possibility but to advance the consummation of history into the future. In King Lear apocalypse is not a certainty, nor even a likelihood, but only a perhaps_-dependent not upon a divine hand to alter the course of history but upon individual men to transform themselves and then perhaps history .... The whole process of salvation involves an apocalypse of mind wherein man, instead of transcending his nature, improves himself through spiritual evolution. (Wittreich 1984, pp. 32-33) ${ }^{46}$

David Lyle Jeffrey argues that generally, for biblically influenced literature, "[I]n apocalyptic texts there is a radical break between history and the new kingdom. Apocalypse grows out of a conviction that most persons and institutions are irredeemably corrupt, fit only for destruction. To this end, it expresses pessimism or despair; but it is also inspired by unshakeable faith that God will put everything right for a virtuous few" (Jeffrey 1992, p. 46); by contrast, according to Wittreich, in Lear "the essential task is to rescue Apocalypse and read it back into the human world; and [Shakespeare's] way of dealing with that problem is to demystify the Apocalypse and thereby humanize it-is to turn responsibility for the shaping of history over to man and thereby secularize the Christian prophecy" (Wittreich 1984, pp. 124-25). From a "more radical" and yet "less apocalyptic" perspective than the orthodox hope that Christ would be the one to establish a perfect kingdom, Shakespeare "sees man himself-at great personal cost and through tremendous sacrifice-moving slowly toward an ideal state" (Wittreich 1984, p. 125). Wittreich does see a resurrection in Lear-but it is confined to spirit, not body, and the operation of this resurrected spirit is itself confined to history, not eternity.

The references to redemption (including those in Job) and to apocalypse (including the expectation of Christ somehow establishing a new kingdom on earth) encourage re-investigation of the possibility of Cordelia as a Christ figure, a role that Wittreich in his secularizing analysis and Maillet in his theologizing analysis modify or reject for opposite reasons. Maillet wants Cordelia to be a Christian pointing to Christ, not a savior herself; Wittreich wants virtuous humans to be replacements for a divine redeemer, where "History" may be saved even if individual souls are not. ${ }^{47}$ My own perspective aligns with Hannibal Hamlin's simple admission that Cordelia is indeed a Christ-figure. The biblical allusions support it, and the literary technique was ubiquitous in Shakespeare's day (Hamlin 2013, p. 71). By necessity, like all Christ-figures in literature, Cordelia is not a perfect corollary to Christ; all analogies

46 A distinguished Milton scholar, Wittreich must have seen what King Lear and Paradise Lost share: each is a literary masterpiece developing from and in tension with biblical narrative, vision, and imagery, a rich history of interpretive cruxes that affect the reading of the work's very foundations, revisited over centuries without definitive resolution, and a significant ultimate turn to psychological and spiritual interior spaces indicated by "the heart." In Paradise Lost, given Milton's narrative persona (Milton 2005), who sought a muse preferring "before all temples th' upright heart and pure," and who described his exterior environment as "in darkness and with dangers compassed round," the final book's postlapsarian turn to the "paradise within" was predictable (Paradise Lost 1.18, 7.27, 12.587). Shakespeare's Lear dies with what is generally considered to be an outward indication, enigmatic as it may be, but my argument is that the biblical allusion to Luke 17 in Lear's "Look there!" redirects the astute spectator to the interior space of the heart. For Wittreich, Lear's redemption is interior, potentially bearing fruit for the future, but limited to earth. One might note that an interior redemption is perfectly compatible with an eternally significant one, as far as Christianity is concerned. For Milton, the fruit of apocalypse transcends this world, involved in Christian doctrines of the afterlife and the resurrection of the body.

47 Wittreich argues that Lear "incorporates no messianic vision" and "the personal tragedy is accentuated by irony-there is a reunion without a restoration, but the tragedy of history is alleviated, the possibility for history as a tragicomedy is allowed for in a play where evil is self-consuming and goodness triumphant in the calm, if not secured order, at its end" (Wittreich 1984, p. 42). 
are imperfect. The difficulty comes in deciding what to make of the parallels that do exist, allowing even for the consideration of her association with Christ being ironic. The passages that mark Cordelia as a potential redeemer and that have generated so much critical attention have already been mentioned; Cordelia might redeem nature from the general curse (4.6.202) and more particularly redeem Lear from all his personal sorrows (5.3.264). She, like Christ, (especially in his Sermon on the Mount and in his confrontation of the Pharisees' hypocrisy) emphasizes the importance of the heart. Her name, as fortunately in the source texts, may be linked to the Latin cors, cordis, drawing attention to the inner life and spiritual integrity she epitomizes, and preparing the spectator for her role as Love in action; her patience and sorrow, smiles and tears in response to news of her father, become a "better way," which Peter Milward reads as suggestive of the "more excellent way" of Love as expressed in 1 Corinthians 13 (Lear 4.3.16-19; Battenhouse 1994, p. 449). She sheds tears of compassion as holy water (4.3.31). The "love, dear love" she has for Lear eventually leads her to prison and to pay (unwittingly) the ultimate price for that love-the loss of her very life (4.4.28).

Lear is filled with emphatic repetitions, and the story of Lear's dependence on Cordelia might be summarized by them from 4.7 onward. When Lear wakes from a healing sleep with fresh garments, his half-belief that the lady in front of him might be his child Cordelia is met with Cordelia's "And so I am, I am" (4.7.70). Her response is simple and profound. The repeated "I am" draws attention to the name by which YHWH identifies himself to Moses in the burning bush (Exodus 3:14), an Old Testament account that the early fathers of the Christian Church read as typological of the incarnation or resurrection of Christ. ${ }^{48}$ It is also the name Jesus uses to identify himself in John 8:58: "Verely, verely I say unto you, before Abraham was, I am." The significance of such a statement was not lost on Jesus' Jewish audience, who tried to stone him for blasphemy. Given the surrounding evidence for her position as a Christ-figure, Cordelia's emphatic "I am" could be read as a similarly significant statement. She is the voice that leads Lear's exodus through fire to freedom.

The second emphatic repetition to note immediately follows Lear's response to Cordelia's self-identification. Facing the daughter he has wronged, Lear says,

If you have poison for me, I will drink it.

I know you do not love me, for your sisters

Have, as I do remember, done me wrong.

You have some cause, they have not. (4.7.72-75)

Cordelia's response- “No cause, no cause" —again and at once simple and profound, signifies her forgiveness, although Lear is still too "far wide" to grasp that his petition for her to "forget and forgive" had been answered before he found the strength to ask $(4.7 .76,50,83-84)$. The words "no cause" may carry no particular biblical allusion, but the experience of unmerited forgiveness wed to intimations of prevenient grace is biblical in concept. At their capture in 5.3, Lear anticipates a life in prison with Cordelia involving a ritual of blessing and forgiveness as well as praying, singing "like birds i'the cage," laughing at "gilded butterflies," and taking up "the mystery of things" (5.3.8-17). Lear has not forgotten the "cause" Cordelia could bring against him, but his exuberance in the assurance that to Cordelia this is "no cause" to mention at all brings him to a nearly ecstatic vision of repeatedly asking (and receiving) her forgiveness. He goes with her to prison in contentment, if not joy.

The next significant set of emphatic repetitions, however, marks an utterly devastating change in fortune. Lear's poetic vision for life with Cordelia in prison is reduced to animal wails: "Howl, howl, howl, howl!" (5.3.255). For what is life without the beloved? "Cordelia, Cordelia ... " (5.3.269); "No, no, no ..." (5.3.304); "Never, never, never, never, never" (5.3.307). The agony is fresh, the tone is hollow. A newfound hope has been wrenched from Lear just as he had begun to see his daughter's true

48 See, for example, The Life of Moses 2.17-26 (Gregory of Nyssa 1978, pp. 58-61) and On the Holy Trinity 2.13 (Augustine 2007, pp. 48-49). 
value. The biblical allusions sprinkled throughout the play lead the spectator to consider the world of Lear in the light of Christianity, introducing the concepts of hope, redemption, and even resurrection; nonetheless, a spectator or reader might determine the ultimate effect of introducing such biblical allusions and Christian references is to intensify the devastation at its conclusion. As the play's last scene unfolds The Tragedy of King Lear remains a tragedy. The pagan setting remains pagan. The absent gods remain absent. To this environment is added extraordinary suffering, agonizing grief at the violent death of a beloved daughter, and, finally, the death of the weary protagonist. Yet, at Lear's last moment, he inserts one final, enigmatic, emphatic repetition: "Look there, look there!"

\section{5. "Look There" in Lear and Luke 17}

Without desiring to brush away the rich ambiguities and interpretive cruxes of the tragedy's ending, or smooth away the sorrow, in this last section I seek to illumine one corner of the critical conversation by examining what I consider to be a profoundly relevant scriptural echo in Lear's last words in the First Folio. I am unaware of any scholarly examination connecting Lear's "Look there, look there!" to Luke 17:20-23, yet making this connection adds relevant layers of meaning enhanced by their shared themes of apocalypse, kingdom, sight/insight, and the importance of the heart. The potential allusion bears upon the interpretation of Cordelia as living Christ-figure, then as the piteous image of innocence martyred, and finally as a sign of the interior space one might call the kingdom of the heart. Such an allusion challenges our reading of the play's presentation of "last things," providing some guidance in what one might look for at the play's ending — and where one might look for it.

Among the gospel narratives, the Book of Luke has had special literary influence, and it remains one of the most important biblical sources for Shakespeare. Donald Thomas Carlson, arguing for a "Lucan parallel" in The Tempest, lists reasons Shakespeare may have been especially drawn to the gospel of Luke. Carlson tentatively suggests that Luke's traditional occupation as physician would make him a suitable authority to introduce into plays with purgatorial or purgative themes; the content of Luke's gospel prevalently addresses the theme of forgiveness. Furthermore, Luke was held to be the most literary of the evangelists; he includes more parables than the other gospels do, and his figures of speech might appeal to a poet and dramatist (Carlson 1991, pp. 1-3). Samuel Taylor Coleridge wrote in his Notebooks that the literary quality of Luke far excelled the Gospel of Matthew, in the way a "splendid poem" by Southey or Scott far outshines its source, a "rude tale in an old chronicle" (qtd. in Jeffrey 1992, p. 466). To the literary qualities of Luke, one might add strong socio-political concerns. As Jeffrey has argued, "More than any other writer in the New Testament, Luke reveals in-depth acquaintance with contemporary political and economic realities ... . Luke emphasizes uprightness as adjunct to piety, stresses proper use of wealth, and encourages a broad social outreach which embraces women, the afflicted, and other marginal people" (Jeffrey 1992, p. 466). In this respect, Luke teaches what Lear learns.

The presence of the Gospel of Luke as intertext to Shakespeare's King Lear is unmistakable. A frequently noted example of this occurs as Cordelia returns to Albion in Act 4. As she prepares for battle with the British powers, she says, "O dear Father, / It is thy business that I go about" (4.4.23-24), alluding to the words of the boy Jesus in the temple, as described in Luke and only Luke among the canonical gospels. In the biblical story, Mary and Joseph return from observing the Passover in Jerusalem to discover that the twelve-year-old Jesus is not among their company of travelers. After three days' search, Mary finds her son in the temple courts talking with the teachers of the Law. She reacts with questioning, perhaps even chastening words: "Sonne, why hast thou thus dealt with us? behold, thy father and I have sought thee with very heavie hearts" (Luke 2:48). Jesus responds, "How is it that yee sought me? knew yee not that I must goe about my Fathers busines?" (Luke 2:49). Luke remarks that Mary and Joseph "understood not the word that he spake to them" (v. 50). Lear also lacks full understanding of the wisdom of his child, and the difficulties the boy Jesus and Cordelia share in explaining their actions to their parents have been noted by Skulsky (1966, p. 13). Cordelia's arrival in Dover with an army is motivated by "love, dear love, and our aged father's right" (4.4.28). 
While one critic has associated Cordelia with the socially outcast woman who anoints Jesus' feet in Luke 7 (and thence Lear with Christ), in going about her father's business, seeking to restore his kingdom to him, she more directly presents herself as a young Christ-figure in the place where she will soon lose her life. ${ }^{49}$

Luke's parables, especially the series of forgiveness parables in Luke 14-16, also influence Lear. Parallels between Lear and the parable of the rich man and Lazarus in Luke 16:19-31 have already been mentioned in consideration of Lear's and Gloucester's developed sympathy with the poor; parallels have also been drawn between Kent and the shrewd manager in Luke 16:1-13, and between Lear and the prodigal son in Luke 15:11-32. ${ }^{50}$ Each of these parables is exclusive to the gospel of Luke. The comparison between Lear and the prodigal son is the most prevalent one. In Shakespeare's play, the roles of father and child are reversed: Lear, the "child-changed father," generally is considered the reckless prodigal who must "come to himself" before reuniting with the daughter whom he had rejected, and who yet loves him, restoring him with compassion and a kiss (Lear 4.7.17, 26-29; Luke 15:17, 20). The parable's central concern of forgiveness for the repentant is enhanced with the image of new garments signifying an unmerited fresh start; in Lear it is Cordelia who arranges "fresh garments" to be put on the king as he sleeps (4.7.20-22). When Lear wakes, Cordelia imagines her father's past sorrows including "hoveli[ing] with swine" — the very bottom of fortune's wheel as experienced by the young Jewish prodigal in Jesus' parable (4.7.39; Luke 15:15-16). The prodigal son's return to the father becomes an occasion for great rejoicing: "For this my sonne was dead, and is alive againe: and he was lost, but he is found" (v. 24). In Lear, in the 4.7 reconciliation scene where the bulk of allusions to the prodigal son parable may be found, Lear is also in a sense recalled to life, even though in his shame (and perhaps desire for purgatorial fires) he repines, "You do me wrong to take me out o'the grave" (4.7.45)

With such correspondences, one might not be surprised to discover other parallels between King Lear and the gospel of Luke. Luke also contains two chapters (17 and 21) that are concerned with apocalypse. St. John's vision on Patmos is not the only reference to apocalypse in Christian sacred scripture; the gospel accounts record Jesus' teachings on the topic. The description of the "dayes of vengeance" in Luke 21 resounds in Gloucester's litany of environmental, social, and political troubles in Act 1, scene 2:

Love cools, friendship falls off, brothers divide; in cities, mutinies; in countries, discord; in palaces, treason; and the bond cracked 'twixt son and father ... Machinations, hollowness, treachery, and all ruinous disorders follow us disquietly to our graves. (Lear 1.2.106-9, 113-114)

In Luke 21, "The dayes of vengeance" are marked by betrayal by "parents ... brethren, and kinsmen, and friends" (v. 16), "warres and seditions" (v. 9), kingdoms rising against kingdoms (v. 10), and situations where "mens hearts shal faile them for feare" (v. 26). Gloucester attributes the ruptures in nature and natural bonds he observes to "late eclipses in the sun and moon" that "portend no good to us" (1.2.103); Luke 21 prophesies "signes in the sun, and in the moone, and in the starres, and upon the earth trouble among the nations with perplexitie; the sea and the waves shall roare" (v. 25; cf. references to the turbulent sea in Lear 3.1.4-6, 3.4.10, 3.7.58-60, 4.4.1-2). Jesus' instructions to his disciples, "By your patience possess your soules" (v. 19) and "Look up ... for your redemption draweth nigh" (v. 28) might also be associated with the persistent question of Lear's own patience and Edgar's final petition, "Look up, my lord" (5.3.311). The parallels between Gloucester's apocalyptic vision and Luke 21 could be analyzed in far greater depth, but it is the other apocalyptic chapter, Luke 17, that concerns Lear most.

49 For the association of Cordelia with the woman in Luke 7:37-50, see (Lefler 2010).

50 For the parable of the shrewd manager and Lear, see (Brisman 1998). For the parable of the prodigal son and Lear, see (Snyder 1966; Milward 1969; Cunningham 1984; Tippens 1988). 
Amid longstanding concern about where and how Lear looks, what pagan and Christian elements may be permitted, and what to make of apparently biblical language and imagery in the play, no one has yet examined in Lear's last words a significant and troublesome biblical allusion to Luke 17. Richmond Noble finds allusions to 22 biblical passages in Lear, and in appendix records allusions throughout Shakespeare's plays to multiple verses from twenty-one of Luke's twenty-four chapters, but in either case provides nothing for Luke 17 (Noble 1970, pp. 294-95). With a more inclusive approach and an eye for the probable rather than the certain, Naseeb Shaheen finds allusions from each of Luke's chapters in Shakespeare (171 verses or passages from Luke in total, many of these alluded to more than once in Shakespeare's works); he lists twelve references to Luke 17 in Shakespeare's plays, but none in Lear (Shaheen 1999, pp. 808-812). Among these, he identifies allusions to verse 29 most frequently (four times, in Twelfth Night, Richard 2, Othello, and Pericles), but this is due to the interjection "Fire and Brimstone," often used comically in Shakespeare. Like Lear, much of Luke 17 is apocalyptic in topic, but Joseph Wittreich's scholarship on apocalypse in Lear does nothing with this particular chapter. Yet there is good reason for including Luke 17 among the apocalyptic biblical texts that shape Lear, for this chapter shares with Lear an interest in the topics of kingdom, divine judgment, sight, insight, revelation, and the importance of both the inner spiritual realm and active love.

Luke 17 begins with Jesus warning his disciples against offending "litle ones," exhorting them to extravagant forgiveness, and assuring them of the extraordinary power of faith. The third verse, "If thy brother trespasse against thee, rebuke him: and if he repent, forgive him," might be compared with Edgar's challenge, duel, and then desire to "exchange charity" with his brother Edmund (5.3.124-38, 164). The center of Luke 17 includes the parable of the unthanked servant (cf. Kent) and the story of Jesus healing the ten lepers, of whom only one returned to thank his healer; this section shares with Lear the themes of dutiful service and gratitude/ingratitude. ${ }^{51}$ The rest of the chapter concerns the apocalyptic message about the "comming of the kingdome of heaven," the anticipated appearance of "false Christes," and "After what maner Christe's comming shal be," as expressed in the argument of Chapter 17 in the 1595 Geneva-Tomson Bible, the version Richmond Noble gives good evidence for having been in Shakespeare's possession (Noble 1970, pp. 58-69). Indeed, Shakespeare's play might be illuminatingly read alongside the whole of Luke 17, but the particular verse deserving emphasis is Luke 17:21. Here it is in context, from the Geneva-Tomson translation:

${ }^{20}$ And when he was demaunded of the Pharises, when the kingdome of God should come, he answered them, and said, The kingdome of God commeth not with observation.

${ }^{21}$ Neither shall men say, Lo here, or lo there: for behold, the kingdome of God is within you.

${ }^{22}$ And he said unto the disciples, The dayes will come, when ye shal desire to see one of the dayes of the Sonne of man, and ye shal not see it.

${ }^{23}$ Then they shall saye to you, Beholde here, or beholde there: but goe not thither, neither follow them.

${ }^{24}$ For as the lightening that lighteneth out of the one parte under heauen, shineth unto the other part under heaven, so shall the Sonne of man be in his day.

${ }^{25}$ But first must he suffer many things, and be reproved of this generation.

The "Lo here, or lo there" of Luke 17:21 (rendered "loo here loo there" in the Tyndale (1534), "Lo here, or lo there" in the Great Bible (1539), and "lo here, lo there" in The Bishop's The Bishop's Bible (1568)) is similar enough to Lear's "Look there, look there!" to warrant further investigation. Similarly, the "Beholde here, or beholde there" in verse 23 " Se here se there" in the Tyndale, and "See here, see there" in the Great Bible and the Bishop's Bible) invites comparison with Albany's exhortation,

51 The good servant of Luke 17 calls himself "unprofitable" because he is simply doing his duty; the parable is referred to in the Elizabethan homily "Of the Misery of All Mankinde" to emphasize that no one is good but God (Lancashire 1994). 
"O see, see!" (5.3.303). Perhaps this allusion has been overlooked because today we may not readily think of 'lo' as a shortened form of 'look,' although the OED confirms this (see the second etymology given $s v$. lo, int.1). Granted, where the biblical passage has "here ... there" Shakespeare has emphatic repetitions, but in context the effects are similar. In Luke 17:21, the "here" and "there" of purported locations of the kingdom of God are not contrasted with each other, but paired together in contrast with the authentic location of that spiritual realm: "within you." 52

If Lear's last words indeed allude to Luke 17, how does this affect our reading of the play? Is the last scene "the promised end," as Kent inquires, "or the image of that horror," as Edgar suggests? Or is it something else? In Luke, Jesus warns his disciples not to believe those who, saying "lo here, lo there," point to a partially visible apocalypse or to the coming of the Kingdom of God. This coming, Luke states, will be self-evident, like lightning stretching from heaven to heaven (v. 24). We, with Lear, have seen a storm in the play, and the raw power of Nature, but the indeterminacy-or at least, the disputability — of the play's conclusion suggests that the kingdom of God has not come at the end of Lear, that this is not the promised end. "Goe not thither, neither follow them," Jesus admonishes. There are false Christs. In this, I can agree with Wittreich: "For all the suggestions of end-time that are to be found in King Lear, the play does not produce the promised end-defiantly resisting, instead, the expectations built by its apocalyptic reference" (Wittreich 1984, p. 32). Eclipse-driven hype remains the mark of Gloucester's superstition, and matter for Edmund's scorn. The same allusion to Luke 17 that may be used to support the redemptive role of Cordelia also presents the possibility that Lear has become an unwittingly false prophet. If Lear's "Look there" is regarded as a reference to the eschaton, there remains the possibility that Lear's final words misdirect us-that at the play's close, the audience left darkling, there is only the tragic image of a promised horrific end that, like the thud of a Tenebrae strepitus, reverberates no hollowness. We would then have the corpse of a Christ-figure, but no Resurrection, and no Second Coming. If one accepts apocalyptic references in Lear's final scene as well as the terms of Luke 17:24 for identifying apocalypse, the very fact that the vitality of Cordelia (and thus the redemption of Lear) is disputed will indicate her role as Christ figure has reached its limits in her death. "Ye shal desire to see one of the dayes of the Sonne of man, and ye shal not see it."

If Lear's final indication, whether heavenly or earthly, is indeed a misdirection, wittingly or unwittingly, one still must consider what to make of the corpse onstage. I am assuming Lear's "look there!" points to the body of dead Cordelia-not outward to a vast and meaningless abyss, nor upward to a spirit blissfully ascending to the heavens. Lear's reference to her lips in the preceding line turns the spectator's attention with him to the body of his daughter. But what ought one make of this body? Is it a sacred relic, or a lump of clay? Performance history cannot settle the issue, only present to us a range of options. In Max Reinhart's 1925 production, as Marvin Rosenberg records, “Cordelia lay limp in Klöpfer's arms as if taken down from the cross of life" (Rosenberg 311); this may be contrasted with Benedict Nightingale's description of Sir Robert Stephens's 1993 performance: “On 'she's dead as earth,' the last word full of disgust, Stephens actually kneed the body onto its back as if it were a slab of meat" (Ogden and Scouten 1997, pp. 242-43). Frequently in performance the sacred and the profane are mingled, especially where the aged king's regard for his daughter's corpse leads to awkward exposure of his own failing strength, as in the case of Tommaso Salvini's Lear (1883-1887): "not allowing anyone but himself to touch the beloved body, [Lear] must drag it in with difficulty" (qtd. in Rosenberg 312).

52 The 1560 Geneva notes provide an alternate translation for "within you": “Or, among you." Calvin's explication of Luke 17: 21-22 in The Institutes 2.15.4 reinforces the primary choice of within in the Geneva translations while maintaining the relevance of the alternative among, for, as he argues, "[Christ] reigns ... both within us and without us" (Calvin 1863, vol. 1, p. 429). In the context of Jesus' apocalyptic statements in the synoptic gospels, the Lucan reference to the kingdom of

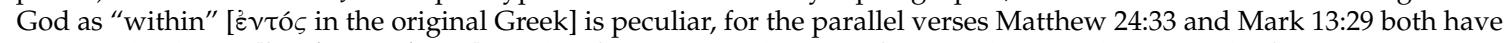

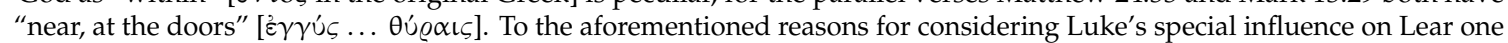
might add a shared emphasis on psychological or spiritual interior spaces in Luke 17 and King Lear. The parallels promote consideration of an allusion in Lear's final words to the "Lo there" of Luke 17:21 rather than to the correlative verses of Matthew 24:23 and Mark 13:21. 
What the theater has not resolved, the scholarly battle lines of the Christianizers and the Existentialists have brought to the level of overdetermination or aporia. The internal evidence of the play cannot resolve it-the absence and silence of the gods neither proves nor disproves the operation of a spiritual realm extending to an afterlife, and even Kent's expectations, implicit in "Vex not his ghost" and "I have a journey, sir" do not establish assurances of any such afterlife within the world of the play $(5.3 .312,320)$. The previously considered biblical allusions clearly present Cordelia as a Christ-figure with redemptive potential-but the text does not show that potential actualized in Lear's pagan world beyond the life of the king, and with her body cradled in his at the end of the play, it is just as difficult to prove that Cordelia's role as redemptrix is ultimately ironic as it is to prove that this piteous Deposition scene is pointing toward a Christian perspective on resurrection and redemption.

If Cordelia is a Christ figure, and Lear's last command is to look upon her corpse, the final words of Lear usher the Jacobean playgoer into one of the heated religious issues of the English Reformation, the image debate in early modern England. What if the body of the hanged Cordelia becomes an object of veneration? Perhaps Lear's fixation on the corpus would be an indication for the Protestant playgoer that Lear is indeed deluded, clinging to a creed outworn. Perhaps the spectacle would be received more sympathetically as a variation of the supreme image evoking pity, a pietà, with the father cradling the dead daughter in his lap, evoking the ghosts of the old Catholicism. ${ }^{53}$ For Cherrell Guilfoyle, who has reminded readers of Lear that the crucifixion of Jesus was traditionally referred to as a hanging (Acts 10:39; Guilfoyle 1989, p. 62), Lear carrying the dead Cordelia onstage "concentrate[s] attention on the relation between Lear and the body of his daughter, and the powerful symbolism of the Deposition and pietà is fed into this final icon" (Guilfoyle 1989, p. 63). For the early modern English Protestant audience, however, there is always the threat that the icon could become an idol. ${ }^{54}$

53 Stephen Greenblatt has argued in Hamlet in Purgatory that Shakespeare "had a particular interest in digging up and redeploying damaged or discarded institutional goods, cultural memories that he returned to his contemporaries and bequeathed to the future" (Greenblatt 2013, p. xiv). Dennis Taylor and David Beauregard have edited a volume of essays, Shakespeare and the Culture of Christianity in Early Modern England, based on the premise that "the ghost of the old Catholicism haunts Shakespeare and his Elizabethan world" (Taylor and Beauregard 2003, p. 12). The question of where Shakespeare's personal religious convictions lay is thorny and not always scholarly. Hannibal Hamlin does a fine job summarizing the key issues and arguments, and remarks that, while arguments for Shakespeare's Catholicism are "gaining the ascendancy," it is also true that "the Catholic Shakespeare remains especially popular among Catholic scholars" (Hamlin 2013, p. 75). In the case of King Lear, one should note that arguments for Lear intimating a Catholic perspective need not be among those arguing for the ultimate redemption of Lear. For Beauregard, the final scene "seems designed as a secular imitation of Michelangelo's Pieta" and "suggests that Shakespeare conceives of nature in Catholic rather than Protestant terms," but ultimately "portrays the deficiency, indeed the horror, of a world apparently without grace and certainly without redemption" (Beauregard 2008, pp. 205, 217).

54 The image of Cordelia's corpse is a contentious but ambiguous one. Treated as a religious image, it cannot settle recent heated debates about Shakespeare's own religious convictions, or even whether his sympathies tended toward the old Roman Catholicism or some sort of Protestantism. On one hand, Erasmus's Praise of Folly provides a notable example of a Catholic humanist satirizing over-attention to religious images; on the other, the Protestant view of images was not uniformly iconoclastic, especially among English Protestants (Davis 2013, pp. 68-69). In one of his sermons John Donne wrote, "there is no necessity of pictures; but will not every man add this. That if the true use of Pictures be preached unto them, there is no danger of an abuse" (qtd. in Davis 2013, p. 68). Donne's measured tolerance of images if properly explained may be contrasted with the Elizabethan Homily Against Peril of Idolatry, which insists that "idolatrie is to Images, specially in Temples and Churches, an inseparable accident (as they terme it) so that Images in Churches, and idolatrie, go alwayes both together, and that therefore the one cannot bee avoyded, except the other (specially in all publike places) bee destroyed" (Lancashire 1994). The image debate continued into the Jacobean period, with the king himself articulating his position in his 1609 Premonition to all most Mighty Monarches, Kings, Free Princes, and States of Christendome:

I am no Iconomachus; I quarrell not with the making of Images, either for publike decoration, or for mens private uses: But that they should bee worshipped, bee prayed to, or any holinesse attributed unto them, was never knowen of the Ancients: And the Scriptures are so directly, vehemently and punctually against it, as I wonder what braine of man, or suggestion of Sathan durst offer it to Christians. (James 1918)

While many early modern Protestants considered venerating religious images idolatrous, there were those whose nuanced positions permitted the use of images as an aid to spiritual devotion. Lutherans, for example, permitted crucifixes, and the reformer Peter Vermigli, whose Loci Communes was published in London in 1583, proposed that Jesus "may be resembled and painted out" (Davis 2016, pp. 126-27; Davis 2013, pp. 105-8). Conversely, John Calvin, in his sermons on Deuteronomy (also published in London in 1583), argued against any images of Christ: "Yes, and therefore whenever a crucifix stands 
In accordance with Jesus' warning in Luke 17:25, perhaps one is foolish even to bother to "look there" at all.

In terms of the early modern image debate, an eikon or image may not be an idol if it serves as an aid to worship something or someone beyond it. For many Protestant Reformers, images, like sacraments, are properly useful only when clearly associated with the Word of God. ${ }^{55}$ What sacred word might be associated with the image of the dead Cordelia? Even the iconoclast might agree that the wrongful use of images is found in the heart of the worshipper, not in the image itself. In the last scene of Lear, even amid all the pathos, we have limited access to the heart of Lear in his last moments of life. One might recollect Alison Shell's suspicion of the "dangerously limited manner" of Lear's redemption (Shell 2010, p. 193).

If the early modern theatergoer saw in the body of Cordelia an imitation of a religious image, what reference might be discovered in the spectacle? What word might be on her unmoving lips? We are commanded to gaze at the dead Cordelia, and left wondering if there is "aught within that little-seeming substance," challenged to decide whether, even in her death, we can yet see the inner value of the princess, that she is herself a dowry $(1.1 .199,243)$. Outwardly, the body of Cordelia is a picture of death, suffering, and injustice. Inwardly, she becomes a sign of truth, love, and sacrifice-not a thing to be worshipped, but a visual aid to worship. Such an image serves as a reminder of the words she had once spoken: "love, dear Love ... "; "I am, I am"; "no cause, no cause." The lips may serve as the outward indication of the heart (cf. Luke 6:45, Matthew 12:34), but Cordelia and Kent have shown that, while there are occasions for speaking out, there are also occasions when one cannot heave one's heart into one's mouth. For those who best know Cordelia's heart, her "Nothing, my lord" is perhaps as meaningful and virtuous as "love, dear Love" $(1.1 .87,4.4 .28)$. Her compassionate action on Lear's behalf signified by the latter phrase is motivated by her personal integrity under pressure, signified by the former. It takes five tragic acts for Lear to know and articulate the value of such a heart.

We are at a crux. Cordelia may become for the spectator a false Christ, an ineffectual Messiah, or an idol—but for those who might see her heart—feelingly, not with ocular observation-even in her death the spectacle of her body on stage might serve as true icon, referring beyond itself to the truth and love Lear has come to recognize and cherish —-the truth and love that, in the midst of great suffering, has transformed him.

In Luke 17, Jesus does not simply negate the storm-chasers. By pointing forward to an unmistakable day of revelation, he silences speculative rumors, but he also directs his disciples to the most immediate place of redemption: "The kingdome of God is within you." It is the interior space of the self-it is the heart-that for now must carry the kingdom of God. And perhaps this is what Lear ultimately sees in Cordelia, and in the process of such a revelation, sparks in himself.

After all, the richest portion of the kingdom has ever been interior. On a literal level, Lear begins the play intending to award his youngest daughter the "more opulent" middle regions of his domain, thereby creating a buffer kingdom separating the lands subjected to the belligerent whims of his first two daughters, their husbands, and their armies (1.1.86). The Fool knows that Cordelia was central to Lear's original plans, not only for the "kind nursery" Lear expects from her for his own person, but also for the peaceful influence her governance would provide the kingdom. According to the Fool's raillery, Cordelia is the nutritious meat of an egg, while Goneril and Regan are the empty half-shells surrounding her (1.4.148-54). She is the nose, keeping the spying eyes on either side of one's face

mopping and mowing in the church, it is all one as if the Devil had defaced the son of God" (Davis 2016, p. 54). For more on reconsidering iconoclasm in early modern England, see (Budd 2000).

55 See (Hutchinson 2017). The Protestant Reformers frequently referred to sacraments as "visible words" that are nevertheless not self-explanatory, and consequently must be joined to the Word of God to be received in understanding and faith. The position is articulated in John Calvin's Short Treatise on the Lord's Supper (sect. 48), which supports its position with reference to Augustine's Tractates on the Gospel of John (Tractate 80). David J. Davis connects Protestant liturgical emphasis on the Word to the early modern image debate: "[A]lthough no longer points of reverence, [religious images] continued to thrive as points of reference" (Davis 2013, p. 69). 
(1.5.19-24). She is the natural locus of wisdom, or would have been, the Fool implies, had Lear kept her inheritance in place. As it stands, however, the Fool chides, "Thou hast pared thy wit o'both sides and left nothing i'the middle. Here comes one o' the parings" (1.4.177-79). The Fool's announcement of Goneril's entrance makes it clear that "nothing I' th' middle" is a lament over the loss of Cordelia as ruler over an interior kingdom. Her substantial political worth as implied in Act 1 is all the more evident in the beginning of Act 2, where Curan informs Edmund of the rumors of imminent war between Albany and Cornwall (2.1.7-12). And yet, from the first mentioning of her heart, Cordelia's association with an interior kingdom is not only physical, but spiritual.

Lear is not redeemed upon evangelical Christian terms. He has not in a burst of illumination received a glimpse of a future Christian era and accepted Jesus Christ as Savior. Lear is not even redeemed in the sense in which Dante redeems a few of his favorite pagans, granting Ripheus and Trajan a place in paradise through divine grace and through their personal virtue. If Lear is redeemed, he is redeemed as a pagan, but through a journey understandable to a Christian audience. If he is in some sense saved, he is saved by Cordelia's heart: by her truth and love.

It is necessary to permit ambiguity. The history of the debate over the ending of Lear is too rich to resolve or explain in a way that satisfies all tastes and accounts for all perspectives within a single thesis. Nonetheless, given the profound thematic and topical parallels between Lear and Luke 17, I remain surprised that Lear's final words have not previously been explored in relation to Luke 17:20-21. It bears repeating: acknowledging this allusion does not remove all ambiguities. Lear's command to "Look there" may yet be the mark of delusion or unwitting deception. Even so, one might arrive at the same conclusion through two pathways. One might "look there" at Cordelia, not as an idolater nor as an iconoclast, but as a sensitive spectator, seeing the body of Cordelia as a religious image properly, as a visual that evokes sincerity in feeling and in worship and leads beyond itself to the Word. Alternatively, mindful of the allusion to Luke 17, one might choose to ignore the command to "Look there" and consider instead how "the kingdom of God is within" the self, and within one's own community. The result is the same: a turn toward a realm that is seen "not with observation" but feelingly, the realm of love resulting in humility, hope, compassion, and active and beneficent service. Hearts work best in King Lear when they are stubborn in their commitment to truth and virtue, and yet fragile in their compassionate response to suffering.

Even as her corpse lies in Lear's arms, Cordelia as image might yet be going about her father's business. If we, like Mary and Joseph, do not have the insight to fully understand this image, and the words she has spoken that lie behind it, who could blame us? But perhaps Lear, who began the play by seeking partial, outward manifestation of his daughters' love-through words if not through deeds-has come to realize what is in Cordelia's heart—not only her innocence, for that he discovered earlier, but also a certain sacred, living kingdom. Here, in the heart, is the apocalypse, understood properly as a revelation, and the anagnorisis of the tragedy, and the promise of life to come. Perhaps Lear's last words point to the apocalyptic warnings of Luke 17, as well as to Job and one of the most vivid intimations of the doctrine of the resurrection of the body in Hebrew sacred scripture:

"For I am sure that my redeemer liveth, and he shall stand the last on the earth. And though after my skinne wormes destroy this body, yet shall I see God in my flesh. Whom I my selfe shall see, and mine eyes shall beholde, and none other for me, though my reins are consumed within me." (Job 19:25-27) ${ }^{56}$

Shakespeare's play is profoundly, fantastically, exuberantly ambiguous. Perhaps this is partly because the existence and location of kingdom must be decided in the heart of the reader. To each his own. Broadening the context of our intertext, one may find in Luke 17:33 the promise that "Whosoever

56 In Hebrew sacred scriptures, the reins (kidneys) were the seat of affections or feelings, in correspondence with our metaphoric understanding of the heart today. 
will seek to save his soule shall lose it; and whosoever shall lose it, shall get it." Perhaps it is only as he loses it that Lear can be every inch a king.

Funding: This research received no external funding.

Conflicts of Interest: The author declares no conflict of interest.

\section{References}

Augustine. 2007. On the Holy Trinity. In Nicene and Post-Nicene Fathers: First Series. Edited by Philip Schaff. New York: Cosimo, vol. 3.

Battenhouse, Roy, ed. 1994. Shakespeare's Christian Dimension: An Anthology of Commentary. Bloomington: Indiana University Press.

Beauregard, David N. 2008. Human Malevolence and Providence in King Lear. Renascence 60: 199-223.

Benson, Sean. 2009. Shakespearean Resurrection: The Art of Almost Raising the Dead. Pittsburgh: Duquesne University Press.

Bloom, Harold. 1989. Ruin the Sacred Truths: Poetry and Belief from the Bible to the Present. Cambridge: Harvard University Press.

Bonheim, Helmut, ed. 1960. The King Lear Perplex. Belmont: Wadsworth.

Bradley, Andrew Cecil. 1991. Shakespearean Tragedy: Lectures on Hamlet, Othello, King Lear, and Macbeth. New York: Penguin.

Brisman, Leslie. 1998. Biblical Revisionism. New Literary History 29: 273-93. [CrossRef]

Budd, Joel. 2000. Rethinking Iconoclasm in Early Modern England: The Case of the Cheapside Cross. Journal of Early Modern History 4: 379-404. [CrossRef]

Burgess, William. 1903. The Bible in Shakespeare. New York: Crowell.

Calvin, John. 1863. Institutes of the Christian Religion. Translated by Henry Beveridge. 2 vols. Clark: Edinburgh, Available online: http://www.ccel.org/ccel/calvin/institutes.i.html (accessed on 27 July 2019).

Campbell, Oscar James. 1948. The Salvation of Lear. ELH 15: 93-109. [CrossRef]

Carlson, Donald Thomas. 1991. 'Charity never falleth away': The Tempest and Shakespeare's Use of Biblical Allusion. Ph.D. dissertation, University of Dallas, Irving, TX, USA.

Carson, Christie. n.d. The Quarto of King Lear-Representing the early stage history of the play? In Treasures in Full: Shakespeare in Quarto. London: The British Library, Available online: https:/www.bl.uk/treasures/ shakespeare/lear.html (accessed on 27 July 2019).

Carson, Susannah, ed. 2013. Living with Shakespeare: Essays by Writers, Actors, and Directors. New York: Vintage.

Carter, Thomas. 1905. Shakespeare and Holy Scripture. London: Hodder and Stoughton.

Chambers, Raymond Wilson, ed. 1940. King Lear. Glasgow: Jackson.

Coleman, Hamilton. 1955. Shakespeare and the Bible. New York: Vantage.

Colie, Rosalie. 1974. The Energies of Endurance: Biblical Echo in King Lear. In Some Facets of King Lear: Essays in Prismatic Criticism. Edited by Rosalie Colie and F. T. Flahiff. Toronto: University of Toronto Press, pp. 117-44.

Colton, Gardner Quincey. 1888. Shakespeare and the Bible. New York: Knox.

Craik, T. W. 1981. I know when one is dead, and when one lives. Proceedings of the British Academy 65: 171-89. Available online: https://www.thebritishacademy.ac.uk/sites/default/files/65p171.pdf (accessed on 27 July 2019).

Croall, Jonathan. 2015. Performing King Lear: Gielgud to Russell Beale. London: Bloomsbury Arden Shakespeare.

Cunningham, John. 1984. King Lear, the Storm, and the Liturgy. Christianity and Literature 34: 9-30. [CrossRef]

Curran, John E., Jr. 2018. That Suggestion: Catholic Casuistry, Complexity, and Macbeth. Religions 9:315. [CrossRef]

Davis, David J. 2013. Seeing Faith, Printing Pictures: Religious Identity during the English Reformation. Leiden: Brill Academic.

Davis, David J. 2016. From Icons to Idols: Documents on the Image Debate in Reformation England. Eugene: Pickwick. Eaton, Thomas Ray. 1858. Shakespeare and the Bible. London: Blackwood.

Ebert, Roger. 1972. Review of King Lear, dir. Peter Brook. October 31. Available online: http://www.rogerebert.com/ reviews/king-lear-1972 (accessed on 27 July 2019).

Elton, William R. 1988. King Lear and the Gods. Lexington: The University Press of Kentucky. 
Erasmus, Desiderius. 1983. The Handbook of the Militant Christian. In The Essential Erasmus. Translated and Edited by John P. Dolan. New York: Meridian, pp. 24-93.

Erasmus, Desiderius. 1993. The Praise of Folly. Translated and Edited by A. H. T. Levi. New York: Penguin.

Fisch, Harold. 1999. The Biblical Presence in Shakespeare, Milton, and Blake: A Comparative Study. Oxford: Clarendon Press.

Frye, Roland Mushat. 1963. Shakespeare and the Christian Doctrine. Princeton: Princeton University Press.

Geneva-Tomson Bible. 1595. The Bible, That Is, the Holy Scriptures Conteined in the Olde and New Testament. London. Available online: https://archive.org/details/biblethatisholys00toms/page/n931 (accessed on 27 July 2019).

Geoffrey of Monmouth. 1966. The History of the Kings of Britain. Translated by Lewis Thorpe. London: Penguin.

Gielgud, John. 1963. Stage Directions. London: Heinemann.

Granville-Barker, Harley. 1940. Prefaces to Shakespeare: First Series. London: Sidgwick \& Jackson.

Greenblatt, Stephen. 2013. Hamlet in Purgatory. Princeton: Princeton University Press.

Gregory of Nyssa. 1978. The Life of Moses. Translated by Abraham J. Malherbe, and Everett Ferguson. New York: Paulist Press.

Grimm, Harold J., and Helmut T. Lehmann, eds. 1957. Luther's Works. Vol. 31: Career of the Reformer I. Philadelphia: Muhlenberg Press.

Guilfoyle, Cherrell. 1989. The Redemption of King Lear. Comparative Drama 23: 50-69. [CrossRef]

Halio, Jay L. 1994. Introduction. In The First Quarto of King Lear. Edited by Jay L. Halio. Cambridge: Cambridge University Press, pp. 1-28.

Hamlin, Hannibal. 2013. The Bible in Shakespeare. Oxford: Oxford University Press.

Holahan, Michael. 1997. 'Look, her Lips': Softness of Voice, Construction of Character in King Lear. Shakespeare Quarterly 48: 406-31. [CrossRef]

Holinshed, Raphael. 1587. Chronicles of England, Scotland, and Ireland. London. Available online: http://english. nsms.ox.ac.uk/holinshed/texts.php?text1=1587_0135 (accessed on 27 July 2019).

Holloway, John. 1961. The Story of the Night: Studies in Shakespeare's Major Tragedies. London: Routledge \& Kegan Paul.

Hutchinson, Eric J. 2017. Sacraments as Visible Words: The Patristic Roots of the Reformation (4). The Calvinist International. October 3. Available online: https://calvinistinternational.com/2017/10/03/sacraments-visiblewords-patristic-roots-reformation-4/ (accessed on 27 July 2019).

Ioppolo, Grace. 2016. Textual Introduction. In The Norton Shakespeare, 3rd ed. Edited by Stephen Greenblatt, Walter Cohen, Suzanne Gosset, Jean E. Howard, Katharine Eisaman Maus and Gordon McMullan. New York: Norton, pp. 1380-83.

James, I. 1918. A Premonition to all most Mighty Monarches, Kings, Free Princes, and States of Christendome. In The Political Works of James I: Reprinted from the Edition of 1616. Edited by Charles Howard McIlwain. Cambridge: Harvard University Press, Available online: http://www.perseus.tufts.edu/hopper/text?doc= Perseus\%3Atext\%3A1999.03.0071\%3Asection\%3D6\%3Asubsection\%3D1 (accessed on 27 July 2019).

Jeffrey, David Lyle. 1992. A Dictionary of Biblical Tradition in English Literature. Grand Rapids: Eerdmans Publishing. Jorgens, Jack J. 1973. The New York Shakespeare Festival 1973. Shakespeare Quarterly 24: 423-27. [CrossRef]

Kirsch, Arthur. 1988. The Emotional Landscape of King Lear. Shakespeare Quarterly 39: 154-70. [CrossRef]

Knight, G. Wilson. 1967. Shakespeare and Religion: Essays of Forty Years. New York: Clarion.

Kott, Jan. 1974. Shakespeare, Our Contemporary. Translated by Boleshaw Taborski. New York: Norton.

Kronenfeld, Judy. 1992. "So Distribution Should Undo Excess, and Each Man Have Enough": Shakespeare's King Lear-Anabaptist Egalitarianism, Anglican Charity, Both, Neither? ELH 59: 755-84. [CrossRef]

Lancashire, Ian, ed. 1994. The Books of Homilies. Renaissance Electronic Texts. Toronto: The University of Toronto, Available online: www.anglicanlibrary.org/homilies/ (accessed on 27 July 2019).

Lander, Jesse M. 2018. Maimed Rites and Whirling Words in Hamlet. In The Bible on the Shakespearean Stage. Edited by Thomas Fulton and Kristen Poole. Cambridge: Cambridge University Press, pp. 188-203.

Lefler, Nathan. 2010. The Tragedy of King Lear: Redeeming Christ? Literature and Theology 24: 211-26. [CrossRef] Leggatt, Alexander. 2004. King Lear: Shakespeare in Performance. Manchester: Manchester University Press.

Lieblein, Leanore. 1987. Jan Kott, Peter Brook, and King Lear. Journal of Dramatic Theory and Criticism 1: 39-49.

Maillet, Greg. 2016. Learning to See the Theological Vision of Shakespeare's King Lear. Newcastle upon Tyne: Cambridge Scholars Publishing.

Marx, Steven. 2000. Shakespeare and the Bible. Oxford: Oxford University Press. 
Maxwell, James Coutts. 1950. The Technique of Invocation in King Lear. Modern Language Review 45: 142-47. [CrossRef]

Melanchthon, Philip. 2014. Commonplaces (Loci Communes 1521). Translated and Edited by Christian Preus. St. Louis: Concordia Publishing House.

Milton, John. 2005. Paradise Lost. Edited by Gordon Teskey. New York: Norton.

Milward, Peter. 1969. The Religious Dimension of King Lear. Shakespeare Studies (Japan) 8: 48-73.

Milward, Peter. 1987. Biblical Influences in Shakespeare's Great Tragedies. Bloomington: Indiana University Press.

More, Thomas. 2003. Utopia. Translated and Edited by Paul Turner. New York: Penguin.

Muir, Kenneth. 1984. King Lear: Critical Essays. London: Routledge.

Nauert, Charles G. 1998. Humanism as Method: Roots of Conflict with the Scholastics. The Sixteenth Century Journal 29: 427-38. [CrossRef]

Noble, Richmond. 1970. Shakespeare's Biblical Knowledge and Use of the Book of Common Prayer as Exemplified in the Plays of the First Folio. New York: Octagon Books.

Oates, Joyce Carol. 1974. "Is This the Promised End?": The Tragedy of King Lear. The Journal of Aesthetics and Art Criticism 33: 19-32. [CrossRef]

Ogden, James, and Arthur H. Scouten, eds. 1997. Lear from Study to Stage: Essays in Criticism. Madison: Fairleigh Dickinson University Press.

Ristad, Eric Sven. 1985. Excellent Production of Butchered King Lear. The Tech 105: 8.

Rooney, David. 2019. King Lear: Theater Review. The Hollywood Reporter. April 4. Available online: https: //www.hollywoodreporter.com/review/king-lear-theater-review-1199652 (accessed on 27 July 2019).

Rosenberg, John D. 1966. Lear and his Comforters. Essays in Criticism 16: 135-46. [CrossRef]

Rosenberg, Marvin. 1972. The Masks of King Lear. Newark: University of Delaware Press.

Shaheen, Naseeb. 1999. Biblical References in Shakespeare's Plays. Newark: University of Delaware.

Shakespeare, William. 1994. The First Quarto of King Lear. Edited by Jay L. Halio. Cambridge: Cambridge University Press.

Shakespeare, William. 1997a. King Lear. Edited by Reginald. A. Foakes. London: Methuen Drama.

Shakespeare, William. 1997b. The Riverside Shakespeare, 2nd ed. Edited by Herschel Baker, Anne Barton, Frank Kermode, Harry Levin, Hallett Smith and Marie Edel. Boston: Houghton Mifflin.

Shakespeare, William. 1998. King Lear. Edited by Russell Fraser. New York: Penguin.

Shakespeare, William. 2001. Shakespeare's Sonnets. Edited by Katherine Duncan-Jones. London: Thomson Learning. Shakespeare, William. 2014. The Complete Works of Shakespeare, 7th ed. Edited by David Bevington. Boston: Pearson. Shakespeare, William. 2016. The Norton Shakespeare, 3rd ed. Edited by Stephen Greenblatt, Walter Cohen, Suzanne Gosset, Jean E. Howard, Katharine Eisaman Maus and Gordon McMullan. New York: Norton.

Shell, Alison. 2010. Shakespeare and Religion. London: Methuen Drama.

Siegel, Paul N. 1957. Shakespearean Tragedy and the Elizabethan Compromise. New York: New York University Press. Siegel, Paul. 1968. Shakespeare's Kneeling-Resurrection Pattern and the Meaning of King Lear. In Shakespeare in His Time and Ours. Notre Dame: University of Notre Dame Press, pp. 108-21.

Skulsky, Harold. 1966. King Lear and the Meaning of Chaos. Shakespeare Quarterly 17: 3-17. [CrossRef]

Smith, Bruce R. 2006. Speaking what we feel about King Lear. In Shakespeare, Memory and Performance. Edited by Peter Holland. Cambridge: Cambridge University Press, pp. 23-42.

Snyder, Susan. 1966. King Lear and the Prodigal Son. Shakespeare Quarterly 17: 361-69. [CrossRef]

Soloski, Alexis. 2019. King Lear Review-Glenda Jackson dominates flawed Broadway show. The Guardian. April 4. Available online: https:/www.theguardian.com/stage/2019/apr/04/king-lear-shakespeare-glenda-jacksonbroadway (accessed on 27 July 2019).

Spenser, Edmund. 1987. The Faerie Queene. Edited by Thomas P. Roche Jr. New York: Penguin.

Stern, Tiffany, ed. 2003. King Leir. New York: Routledge.

Summers, Joseph. 1980. “Look there, look there!": The Ending of King Lear. In English Renaissance Studies: Presented to Dame Helen Gardner in Honour of her Seventieth Birthday. Oxford: Clarendon Press, pp. 74-93.

Taylor, Dennis, and David Beauregard, eds. 2003. Shakespeare and the Culture of Christianity in Early Modern England. New York: Fordham University Press.

Taylor, Gary, and Michael Warren, eds. 1983. The Division of the Kingdoms: Shakespeare's Two Versions of King Lear. Oxford: Oxford University Press. 
The Bishop's Bible. 1568. The Holie Bible: Conteyning the Olde Testament and the New. London. Available online: https://archive.org/details/holiebiblecontey00lond/page/n1411 (accessed on 27 July 2019).

The Geneva Bible. 1560. The Bible and Holy Scriptures Conteyned in the Olde and New Testament. London. Available online: https://archive.org/details/TheGenevaBible1560 (accessed on 27 July 2019).

Tiffany, Grace. 2018. Paganism and Reform in Shakespeare's Plays. Religions 9: 214. [CrossRef]

Tippens, Darryl. 1988. Shakespeare and the Prodigal Son Tradition. Explorations in Renaissance Culture 14: 57-78. [CrossRef]

William Tyndale, trans. 1534. William Tyndale's 1534 Biblical Translations. Available online: www.tyndalebible. com (accessed on 27 July 2019).

Urban, David V. 2019. Prospero, the Divine Shepherd, and Providence: Psalm 23 as a Rubric for Alonso's Redemptive Progress, and the Providential Workings of Prospero's Spiritual Restoration in Shakespeare's The Tempest. Religions 10: 448. [CrossRef]

Van Domelen, John E. 1975. Why Cordelia Must Die. South Central Bulletin 35: 132-35. [CrossRef]

Vickers, Brian. 2016. One King Lear. Cambridge: Harvard University Press.

Wells, Stanley. 2000. Introduction. In King Lear. Edited by Stanley Wells. Oxford: Oxford University Press, pp. 1-80. Wittreich, Joseph. 1984. "Image of That Horror": History, Prophecy, and Apocalypse in King Lear. San Marino: Huntington Library.

(C) 2019 by the author. Licensee MDPI, Basel, Switzerland. This article is an open access article distributed under the terms and conditions of the Creative Commons Attribution (CC BY) license (http://creativecommons.org/licenses/by/4.0/). 